\title{
Factors Affecting Delays in Rail Transportation Projects Using Analytic Network Process: The Case of Iran
}

\begin{abstract}
Delays in the implementation and commissioning of rail transportation projects can cause economic damages to project stakeholders and the cities linked by such rail networks. Hence, the current study aims to investigate the key delay factors and provides salient recommendations. In this study, multi-criteria decision-making - the Analytic Network Process (ANP) and the DEMATEL (Decision Making trial and evaluation laboratory) method was employed to help decision-makers in prioritizing these delay factors and evaluating their interactions, respectively. A Delphi approach was used to validate the study's findings via expert questionnaire surveys - based on a rail transportation development project for the Mobarakeh Steel Complex (MSC). The study's findings revealed the management factors as the most important delay factors, followed closely by the financial, design, and implementation factors. Other potent issues include the existence of numerous decision-making stations, lack of central role, and sufficient authority for the project managers are responsible for project delays. Overall, the results show that resolving problems with the 'management' domain can significantly avoid or alleviate the extent of delays in rail transportation development projects. The study's findings and recommendations can serve as a policy and consultative instrument for the relevant stakeholders in the railway industry.
\end{abstract}

Keywords: Project delays; Rail transportation project; Analytic Network Process (ANP); DEMATEL; Iran 


\section{Introduction}

A large portion of resources in most countries are spent on infrastructural and development projects. Road and transportation development projects, including railway development projects, are among the focal infrastructural projects in an economic. The importance of rail transportation projects is due to the essential role and high priority of rail transportation in improving infrastructures and creating a balanced and sustainable development (Wang et al., 2018; Cigu et al., 2019). Furthermore, the vital role of rail transportation in the Gross Domestic Product (GDP), and its necessity for development in economy, trade, industry, agriculture, financial and social sectors cannot be overstated (Wang et al., 2018). The advantages of rail transportation over road transportation for transportation of large quantities of cargo and passengers, especially for long distances include significant reduction in energy consumption, significantly higher safety and positive effects on the environment due to reduced fuel consumption and reduced cost of transportation (Arvin et al., 2015).

Evidence acquired from studies in Europe, the United States, and China show that rail transportation offers significant environmental and safety advantages when compared to road transportation (Phang, 2003; Mohri \& Haghshenas, 2017; Wang et al., 2018; Cigu et al., 2019). Most experts and decision-makers believe that the development of countries is dependent on the development of their transportation networks and consider the transportation industry as one of the main infrastructures necessary for growth (Sojoodi et al., 2012; Aldagheiri, 2010). Therefore, following the predicted schedule for the implementation of transportation projects is one of the necessary factors in development. Mahdi and Soliman (2018) reported that delays in projects affect the early use of such projects by the clients.

The success of any construction project (through evaluation of its goals) is based on predicted cost and schedule targets, which results in significant improvement of the project's desirability and profits (Hughes et al. 2015). Investigating the records related to construction projects, including rail transportation projects in different countries, indicates that, in some cases, projects fail to follow the initially predicted schedule and sometimes require numerous extensions of their deadline (Han et al. 2009). Since the cost of railway construction in most countries are covered through the national budget, and the role of the private sectors in these investments is negligible the schedule of these projects is often ignored. This results in delays in the construction and commissioning of the majority of railway projects (Behbahani et al., 2012; Shafiepour et al., 2018).

Delays in the implementation and commissioning of railway development projects can result in irreparable damages to the development of countries. Various factors result in delays in construction projects. Furthermore, the effects of these factors are not equal, with some 
factors having more significant effects on the project duration and, therefore, the cost of the projects (Han et.al. 2009). An increase in implementation time of projects is often accompanied by a decrease in the direct costs and an increase in the indirect costs of the project. This often results in reduced feasibility of the projects and can cause a significant waste of resources (Adam et al. 2015). These problems, especially in primary industries, can lead to financial loss and, therefore, problems for other sectors and society.

The steel industry is one of the most critical strategic sectors which plays an essential role in the development process of countries, especially for rail transportation (Cyril et al., 2017). Mobarakeh Steel Complex (MSC) is the largest steel manufacturer in the Middle East, and its development, expansion, and maintenance, as one of the strategic industries, is essential for Iran. Each year, large investments are made for expansion, development, and maintenance of various parts of this complex. Among these investments, the development of rail transportation networks is one of the key projects of MSC. Estimations indicate that along with a decrease in transportation time and improved environmental friendliness, the use of rail transportation results in a $20 \%$ decrease in transportation costs for raw materials and final products when compared to road transportation (MSC website).

Statistics also show that more than 16,415 thousand metric tones of raw materials and 2,150 thousand metric tons of finished products of MSC have been transported using railway networks in March 2017 to March 2018 period. This means that rail transportation used $26.7 \%$ of the products of this complex. Therefore, the timely construction of rail transportation networks is one of the priorities of MSC. This means that identification and evaluation of factors causing delays in these projects are necessary for preventing future delays.

Meanwhile, in recent years, multi-criteria criteria decision-making (MCDM) techniques, such as Analytic Hierarchy Process (AHP) and ANP have been applied to prioritize the critical success factors for project risk assessment. ANP is a generalization of AHP which is more capable of a better and accurate predictions as well priority calculations in cases of networks with dependent criteria. Meanwhile, Decision-Making Trial and Evaluation Laboratory (DEMATEL) is a useful method to analyze and determine the relationship between cause and effect. Consequently, in the last few years there has been a growing interest in integrating DEMATEL with ANP method for MCDM (Ji et al., 2018). In previous research, the ANP and DEMATEL methods have been widely used to assessing and prioritizing delay factors of construction and industrial projects (Cheng and Li, 2005; Dedasht et al., 2017; Ji et al., 2018; Karamoozian et al, 2019).

Therefore, the current study aims to identify and evaluate the causes of delays for rail transportation projects of MSC from the extant literature and prioritized these factors using the 
Analytic Network Process (ANP) approach. Also, the relationship and interactions between the factors will be evaluated using the DEMATEL technique. The findings of the study will contribute significant to the knowledge and practice of development process of railway transport. It can also serve as a consultative instrument for government agencies and other relevant stakeholders.

The remainder of the paper is organized as into four sections: Section 2 describes causes of delay in railway development projects, Research methodology is presented in Section 3, Section 4 discusses results and discussion; Section 5 concludes the paper.

\section{Causes of delay in railway development projects}

Given the importance of rail transportation network in countries, any delays in the construction of railway projects can create significant losses. Therefore, identification and evaluation of causes of the delays and providing solutions are important to prevent delays in future projects. The specifications of delays and their effects can vary between projects.

VarNaseri et al. (2018), in their study, investigated the reasons for time scheduling failures in railway construction projects. They used an applied study which gathered field information using questionnaire and interviews. Their results indicated that the main reason for delays was in the financial group and due to lack of timely payment of financial statements (VarNaseri et al., 2018). In another study, Zanganeh (2016) investigated the reasons for delays in urban train projects in Iran. His results indicated that the main reasons for the delay were weakness regarding laws and regulations of contractor referral, significant changes in implementation maps or technical specifications, lack of correct pricing by contractors during tenders, lack of fixing oppositions on time and early commissioning of the project due to political and social factors.

Furthermore, weaknesses regarding financing of contractors, lack of sufficient budget allocation during the scheduled project duration, weaknesses in executive management of contractors, long bureaucratic processes in government organizations, low accuracy in volume estimations, lack of executive experience in designers, delays in creation and distribution of implementation plans, and decision-making delays at critical times by the employer were among other reasons for delayed commissioning of urban train projects in Iran (Zanganeh, 2016). El-Kholy (2019) also reported that delay and cost overruns are very common in highway project. Also, El-Kholy (2019) used the artificial neural network to predict percentages of overall delay in highway projects.

In another study, the delays during the construction of the railway connecting Chengannur and Mavelikara in India was investigated. Case study analysis using the "Delay Analysis System" 
showed that the project be delayed for up to 135 months $(11+$ years). The results also indicated that delays in the provision of necessary materials and financial problems were the main reasons for the delays in this project (Aswathi \& Thomas, 2013). Mittal and Paul (2018) also investigated the reasons for delays in the construction of urban railway projects in India. Delays in land ownership and delivery of the project site to the contractors, changes in applications and possible requirements, delayed payments, unpredictable underground effects and changes in the ground conditions, raw material shortage in the market, delays in approval of the project design and decision-making, lack of sufficient workforce, lack of adequate data collection and incomplete investigations before implementation, and delays in acquisition of necessary permits were identified as the most important reasons for delays in these projects (Mittal \& Paul, 2018).

The reasons for delays in the construction of 'line 2' of the urban train in the city of Tabriz was investigated by Nikjou et al. (2009). Their results indicated that the most important reasons for delays included repeated changes in information and documents provided by the employer, the long duration necessary for evaluation and approval of suggestions and designs and signing of contracts, delays due to lack of sufficient financing and credits (delays in payments) and weaknesses in motivational systems for employees. (Nikjou et al., 2009).

In 2004, South Korea became the fifth country in work to use highspeed railways. Uncertainties and numerous challenges in the planning and management stages resulted in delays and an increase in project costs. Identification of the reasons for delays in the 412 kilometer-long highspeed railway project in South Korea was difficult because the KTX project included a total of 11,141 different activities (Han et al., 2009). However, the results of the study showed that the employer's ability and strategy was insufficient for managing a project at such a high technological level.

Repeated changes in the direction due to increased public environmental concerns, insufficient project delivery systems, and lack of sufficient planning tools for such a large project were among other reasons for these delays (Han et al. 2009). Anbarzadeh et al. (2019), in their study, investigated the available documents for Kermanshah urban train project and conducted interviews with executive managers in order to identify the reasons for delays. The results of their study showed that delays in payments to contractors is the significant factor for the long duration of the Kermanshah urban train project. The summary of the factors for delays in railway projects is presented in Table 1. These delay factors are derived from past researches. Railway development and construction projects have a lot in common with construction projects. So, there will be a lot of common delay factors. 
Table 1: The summary of factors for delays in railway construction projects

\begin{tabular}{ll}
\hline \multicolumn{1}{c}{ Reference } & \multicolumn{1}{c}{ Reasons for delay } \\
\hline VarNaseri et.al. (2018) & Financial problems \\
Zanganeh (2016) & Weakness regarding laws and regulations of contractor referral, \\
& Significant changes in implementation maps or technical specifications, \\
& Lack of correct pricing by contractors during tenders, \\
& Lack of fixing oppositions in a timely manner and early commissioning of \\
& the project due to political and social factors \\
& Weaknesses regarding financing of contractors, \\
& Lack of sufficient budget allocation during the scheduled project duration, \\
& Weaknesses in executive management of contractors, \\
& Long bureaucratic processes in government organizations, \\
& Low accuracy in volume estimations, \\
& Lack of executive experience in designers, \\
& Delays in creation and distribution of executive plans, \\
& Decision-making delays at critical times by the employer \\
& Delays in raw material acquisition \\
& Financial problems \\
& Delays in land ownership and delivery of the project site to the \\
& contractors, \\
Aswathi and Thomas & Changes in applications and possible requirements, \\
(2013) & Unpredictable underground effects and changes in the ground conditions, \\
Mittal and Paul (2018) & Raw material shortage in the market, \\
& Delays in approval of the project design and decision-making, \\
& Lack of sufficient workforce, \\
& Lack of sufficient data collection and incomplete investigations before \\
implementation, & \\
Delays in acquisition of necessary permits \\
Hanbarzadeh et.al. (2019) \\
Repeated changes in information and documents provided by the \\
employer, \\
Long duration of evaluation and approval of suggestions and designs and \\
signing of contracts, \\
Delays due to lack of sufficient financing and credits \\
Weaknesses in motivational systems for employees \\
Repeated changes in the direction due to increased public environmental \\
concerns, \\
Insufficient project delivery system, \\
Lack of sufficient planning tools for large projects \\
Delays in payments to contractors during the project \\
\hline
\end{tabular}

\section{Research methodology}

As revealed in section 2, a list of factors affecting the time delays in rail transportation system development projects in MSC were identified. Based on the identified factors causing delay in rail projects, an expert questionnaire survey was developed using the Delphi survey technique (Brady, 2015; Sarvari et al, 2019; Olawumi et al., 2018). Two rounds of Delphi survey were adopted, and the first Delphi survey questionnaire contains 65 factor items which was distributed among 10 experts. After the first round of the Delphi survey, necessary modifications were made based on the experts' opinions and the revised questionnaire 
distributed for the second round of Delphi survey. Finally, the questionnaire was again revised based on experts' opinions with the final questionnaire form containing 48 items. Relevant literature (see Chan et al., 2015; Chan \& Chan, 2012; Olawumi \& Chan, 2018) provided guide in undertaking the Delphi approach.

\subsection{Investigating the content and face validity of the questionnaire}

In this section, the validity of each item was evaluated. Validity evaluates the ability of a test to achieve its intended aim. In other words, a valid test must be suitable for measuring what it intends to measure. The first step in determining the validity of a test is to investigate its content validity. Content validity depends on logical analysis of test content and is determined based on cognitive and personal judgments of individuals.

In order to measure content validity, the tests are presented to experts who are then asked to determine whether each item measures its intended target and whether the items are in line with the overall content of the test or not. In case of agreement between different individuals regarding content validity of the test, the content validity is confirmed (Oktavia et.al., 2018). In this study, the method proposed by Chadwick et.al. (1982) and Lavshy (1975) was employed. Although the method proposed by Lavshy states that the minimum number of members is 4 , we decided to use a higher number of participants in this study.

This decision was made in order to overcome limitations such as people leaving the study and low return rate of questionnaires which increases the reliability of the results. Furthermore, Lavshy (1975) stated the minimum acceptable content validity coefficient is 0.6 . In this regard, Chadwick et.al. (1984) opined that at least eight (8) participants must meet these criteria. Therefore, in the current study, 13 individuals participated in the evaluation of the content validity of the questionnaire. Inclusion criteria for this part of the study included having at least one hour or free time in order to fill the questionnaire (Hassanzadeh et.al., 2012).

\subsubsection{Content Validity Ratio}

Content Validity Ratio (CVR) was first introduced by Lawshe (1957). This ratio is used in order to measure content validity based on experts' opinions. In this method, the aim of the test is explained to the experts who are then asked to score each item using Likert scale between "necessary item", "useful but not necessary item" and "unnecessary item". Then, CVR is calculated using equation (1):

$C V R=\frac{\left[n-\frac{N}{2}\right]}{\frac{N}{2}}$

Where $\mathrm{N}$ is the total number of experts and $\mathrm{n}$ is the number of experts who have selected "necessary item" option. The minimum acceptable CVR value for a total of 13 experts is equal 
to 0.54 (Pezshki et. al., 2017). Items with CVR values lower than this threshold should be eliminated from the test due to lack of suitable content validity.

\subsubsection{Content Validity Index}

Content Validity Index was investigated using Waltz and Bausell approach (1983). In this approach, experts were asked to score each item regarding its "relevance", "clarity" and "simplicity" using a 4-point Likert scale. The experts scored the relevance using 1 ("irrelevant"), 2 ("Somewhat relevant"), 3 ("relevant") and 4 ("fully relevant"). Simplicity was also scored using 1 ("not simple"), 2 ("Somewhat simple"), 3 ("simple") and 4 ("simple and relevant") while clarity was scored using 1 (“unclear"), 2 (“Somewhat clear"), 3 (“clear") and 4 ("clear and relevant"). Then, Content Validity Index was calculated using equation (2):

Content Validity Index $(C V I)=\frac{\text { Number of experts giving } 3 \text { and } 4 \text { scores }}{\text { total number of experts }}$

The minimum acceptable threshold for CVI is 0.79 and items with scores below this threshold are eliminated (Pezshki et.al., 2017; Fadavi-Ghaderi et.al., 2017).

\subsubsection{Investigation of face validity}

Face or Formal validity is a primary and minimal criterion for content validity. This type of validity shows that measured elements are capable of measuring the intended concepts at a face value. In order to measure face validity of the items, the item impact score test is used. In order to calculate item impact scores - First, the participants are asked to score the importance of each item in the questionnaire using a 5-point Likert scale from 1 ("Not important at all"), 2 ("a little important"), 3 ("Somewhat important"), 4 ("important") and 5 ("very important"). Then, impact score is calculated using equation (3):

Impact Score $=$ Frequency $(\%) \times$ Importance

The face validity value of items must not be below 1.5 and only items with impact scores higher that 1.5 are retained (Fadavi-Ghaderi et.al. 2017).

\subsubsection{The result of face and content validity tests}

A total of 13 experts responded to the initial questionnaire. Furthermore, a group panel were asked of their opinions and suggestions regarding delay factors present in the initial questionnaire in order to determine any hidden factors. To this end, the item of "Do you think the grouping is suitable?" was added to the questionnaire. Furthermore, the experts were asked to offer their suggestions under the same question in case of disagreement with the 
grouping. The results of face and content validity evaluations showed that only 16 items have suitable face and content validity scores (see Appendix E).

\subsection{Evaluating the Reliability of the questionnaire}

In this section, the reliability of the items was investigated and items with low reliability are removed in order to improve the overall reliability of the test. Various methods are used to measure reliability. In this study, Cronbach's Alpha coefficient was calculated using the SPSS software. The Cronbach's Alpha value must be higher than 0.7 (Taber, 2018). The Cronbach's Alpha value calculated in the current study was 0.908 which indicates that all items have suitable reliability. After confirming the validity and reliability of the test, the final questionnaire, presented in Table 2, was used to identify and prioritize factors causing delays in rail transportation network development projects of MSC using the ANP.

Table 2: Project Delay Factors

\begin{tabular}{|c|c|c|c|}
\hline Factor & Code & Sub-factor & Code \\
\hline \multirow[b]{2}{*}{ Financial } & \multirow[b]{2}{*}{ Fin } & Lack of budget predictions for new activities in contracts & $1 \mathrm{~F}$ \\
\hline & & $\begin{array}{l}\text { Lack of transparency in general and specific contract conditions } \\
\text { of MSC }\end{array}$ & $2 \mathrm{~F}$ \\
\hline \multirow{4}{*}{ Management } & \multirow{4}{*}{ Mgn } & $\begin{array}{l}\text { Lack of central role for project lead in execution stages } \\
\text { (scattering of decision-makers in projects) }\end{array}$ & $3 \mathrm{M}$ \\
\hline & & $\begin{array}{l}\text { Numerous decision-making points in the project (outside of } \\
\text { implementation deputy) }\end{array}$ & $4 \mathrm{M}$ \\
\hline & & Lack of sufficient authority for project lead in implementation unit & $5 \mathrm{M}$ \\
\hline & & $\begin{array}{l}\text { Lack of timely issuance of work permit (inside workshop) by } \\
\text { operators }\end{array}$ & $6 \mathrm{M}$ \\
\hline \multirow{5}{*}{ Design } & \multirow{5}{*}{ Des } & Lack of correct prediction of contract schedule & $7 \mathrm{D}$ \\
\hline & & $\begin{array}{l}\text { Lack of correct prediction of require time for land and workshop } \\
\text { equipment preparation }\end{array}$ & $8 \mathrm{D}$ \\
\hline & & $\begin{array}{l}\text { Not filling project documents before tender (including maps, } \\
\text { operator confirmations, providers' list, etc.) }\end{array}$ & $9 \mathrm{D}$ \\
\hline & & Inconsistence of plans with estimates attached to contract & $10 \mathrm{D}$ \\
\hline & & $\begin{array}{l}\text { Incompatibility between project implementation method and } \\
\text { contract type (BOT, PC, EPC, etc.) }\end{array}$ & $11 \mathrm{D}$ \\
\hline \multirow{5}{*}{ Executive } & \multirow{5}{*}{ Exe } & $\begin{array}{l}\text { Lack of specialized organizational structure specially in } \\
\text { contractors and supervisors }\end{array}$ & $12 \mathrm{E}$ \\
\hline & & $\begin{array}{l}\text { Lack of engineering coordination between factory, operators, } \\
\text { and executors of the initial plans (especially in EPC projects) }\end{array}$ & $13 \mathrm{E}$ \\
\hline & & $\begin{array}{l}\text { Lack of necessary permits from units involved in the project for } \\
\text { land preparation, conflict resolution, workshop outfitting, etc. }\end{array}$ & $14 \mathrm{E}$ \\
\hline & & Weaknesses in executive management of the contractors & $15 \mathrm{E}$ \\
\hline & & $\begin{array}{l}\text { Lack of sufficient insistence of supervising units for timely } \\
\text { delivery of the project }\end{array}$ & $16 \mathrm{E}$ \\
\hline
\end{tabular}




\section{Results and discussion}

\subsection{Determination of interrelationships between factors and criteria}

The Decision-Making Trail and Evaluation Laboratory (DEMATEL) approach was used to prepare a map of interactions between various factors/criteria in the network. DEMATEL approach can effectively prepare a map of interrelations between factors with clear relations between sub-factors of each factor. Furthermore, this approach can be used to create causation graphs which evaluate the cause and effect relations in the system (Büyüközkan \& Çifçi, 2016). The steps of the implementation of the DEMATEL approach are as bellow:

Step 1: Formation of direct relation matrix: In this step, the pairwise effect of factors on each other is investigated. in order to investigate the effect of factors on each other, a scale with five options is used (Table 3). When the opinions of several individuals are used, the average score for each relation is used (Kaushik, 2015).

Table 3: The DEMATEL questionnaire scales

\begin{tabular}{ccccc}
\hline No effect & Very small effect & Small effect & Large effect & Very large effect \\
\hline 0 & 1 & 2 & 3 & 4 \\
\hline
\end{tabular}

The matrix created in this step is shown in Appendix $A$ with its elements being $a_{i j}$. Each element $a$ is the effect of $i$ factor on the $j$ factor (equation 4). Then, experts' opinions are used for the pairwise comparisons and recording of the results.

$A=\left[a_{i j}\right]=\frac{1}{H} \sum_{K=1}^{H} X$

Step 2: Normalization of direct relation matrix: Equation 5 is used to convert direct relation matrix $A$ to normalized direct relation matrix $D$.

$D=m \times A$

Where, $m=\min \left[\frac{1}{\max _{i} \sum_{j=1}^{n} a_{i j}}, \frac{1}{\max _{i} \sum_{i=1}^{n} a_{i j}}\right], i, j \in\{1,2, \ldots, n\}$

Step 3: Calculation of full relation matrix: After calculation of matrix $D$, which is the normalized direct relation matrix, full relation matrix $T$ can be calculated using equation (6) where "l" is an identify matrix (Kaushik, 2015).

$T=\lim \left(D+D^{2}+\cdots+D^{m}\right)=\sum_{m \rightarrow \infty}^{\infty} D^{i}$

$\sum_{m \rightarrow \infty}^{\infty} D^{i}=D^{1}+D^{1}+\cdots+D^{m}=D\left(1+D^{1}+D^{2}+\cdots+D^{m-1}\right)=D(1-D)^{-1}(1-D)^{m}$

$T=D(1-D)^{-1}$ 
Step 4: Creation of Causation Graph: The sum of elements on the rows and columns of matrix $T$ are shown with vectors $r$ and $c$, respectively (equations 7 and 8 ). The values on the horizontal axis or "importance axis" shows the level of importance for each factor which is calculated as the sum of vectors $r$ and $c(c+r)$. Similarity, the values for the vertical axis or "dependence axis" are calculated based on the difference of these two vectors (c-r). These values help divide the factors into causes and effects. In general, when (c-r) is a positive number, the factor belongs to the cause category and otherwise the factor belongs to the effects' category. Therefore, the causation graph is created by plotting the (c+r, $c-r)$ values for each factor (Kaushik, 2015).

$r=\left[r_{i}\right]_{n \times 1}=\left[\sum_{j=1}^{n} T_{i j}\right]_{n \times 1}$
$c=\left[c_{i}\right]_{n \times 1}=\left[\sum_{i=1}^{n} T_{i j}\right]_{1 \times n}$

Step 5: Creation of network relationship map: It is possible to create a network relationship map (NRM) between various factors. In order to calculate the network relationships, a threshold value $\alpha$ is calculated using the average values of matrix T (equation 9). This can help eliminate partial relationships (all relationships with values below the threshold value) from the causation relation while significant relationships (relationships whose values in matrix T are higher than the threshold value) are shown (Kaushik, 2015).

$\alpha=\frac{\sum_{i=1}^{n} \sum_{j=1}^{n} T_{i j}}{N}$

\subsubsection{The results of DEMATEL approach}

Data analysis using DEMATEL approach showed that the threshold value is equal to 2.5. The causation graph is presented in Figure 1. The results indicated that the financial factor is placed in the causation category; and the management, design, and execution factors are placed in the effect category. Normalization of direct relation matrix and calculation of full relationship matrix for sub-factors was carried out using DEMATEL approach after data analysis. The threshold value in this case is equal to 0.0325216 with values lower than this threshold value being considered as zero. Finally, the model for network relationships was created and confirmed by two statistical experts. The results of data analysis using DEMATEL for factors and sub-factors are shown in Table 4 and 5, respectively. This clarified the internal relations and interactions of the network which are presented in Figure 2. This decision tree includes 4 factors and 16 sub-factors. Also, in order to make these interactions and connections easier to understand, network's internal relationships for factors and sub-factors are presented at appendix B. 


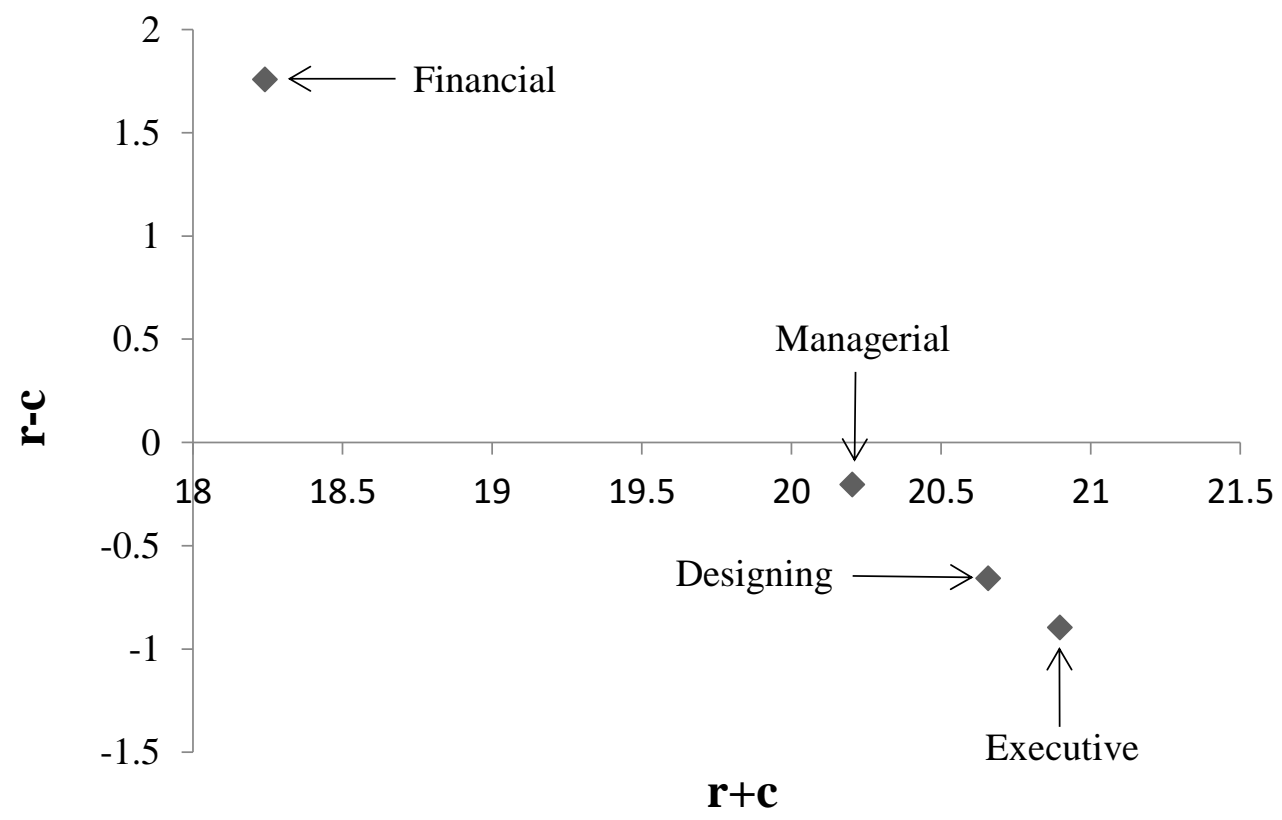

Figure 1: Causation graph

Table 4: The results of data analysis using DEMATEL for factors

\begin{tabular}{ccc}
\hline Factors & $\mathbf{r}-\mathbf{c}$ & $\mathbf{r + c}$ \\
\hline Financial & 1.75861 & 18.241 \\
Managerial & -0.2043 & 20.204 \\
Design & -0.8967 & 2.897 \\
Executive & -0.6576 & 20.658 \\
\hline
\end{tabular}

Table 5: The results of data analysis using DEMATEL for sub-factors

\begin{tabular}{|c|c|c|c|c|c|c|c|c|c|c|c|c|c|c|c|c|}
\hline & $1 F$ & $2 F$ & $3 M$ & $4 M$ & $5 M$ & $6 \mathrm{M}$ & 7D & 8D & 9D & 10D & 11D & $12 \mathrm{E}$ & $13 E$ & $14 E$ & $15 \mathrm{E}$ & $16 \mathrm{E}$ \\
\hline $1 F$ & $\begin{array}{c}0.0021 \\
8\end{array}$ & 0.04373 & $\begin{array}{c}0.000 \\
06\end{array}$ & $\begin{array}{c}0.000 \\
35\end{array}$ & $\begin{array}{c}0.000 \\
06\end{array}$ & $\begin{array}{c}0.000 \\
11\end{array}$ & $\begin{array}{c}0.004 \\
73\end{array}$ & $\begin{array}{c}0.004 \\
67\end{array}$ & $\begin{array}{c}0.002 \\
90\end{array}$ & $\begin{array}{c}0.000 \\
08\end{array}$ & $\begin{array}{c}0.002 \\
34\end{array}$ & $\begin{array}{c}0.000 \\
00\end{array}$ & $\begin{array}{c}0.000 \\
64\end{array}$ & $\begin{array}{c}0.000 \\
96\end{array}$ & $\begin{array}{c}0.000 \\
00\end{array}$ & $\begin{array}{c}0.000 \\
00\end{array}$ \\
\hline $2 F$ & $\begin{array}{c}0.0502 \\
5\end{array}$ & 0.00573 & $\begin{array}{c}0.001 \\
28\end{array}$ & $\begin{array}{c}0.008 \\
02\end{array}$ & $\begin{array}{c}0.001 \\
37\end{array}$ & $\begin{array}{c}0.002 \\
61\end{array}$ & $\begin{array}{c}0.108 \\
90\end{array}$ & $\begin{array}{c}0.107 \\
32\end{array}$ & $\begin{array}{c}0.066 \\
72\end{array}$ & $\begin{array}{c}0.001 \\
92\end{array}$ & $\begin{array}{c}0.053 \\
71\end{array}$ & $\begin{array}{c}0.000 \\
00\end{array}$ & $\begin{array}{c}0.014 \\
74\end{array}$ & $\begin{array}{c}0.022 \\
14\end{array}$ & $\begin{array}{c}0.000 \\
00\end{array}$ & $\begin{array}{c}0.000 \\
00\end{array}$ \\
\hline $3 \mathrm{M}$ & $\begin{array}{c}0.0022 \\
7\end{array}$ & 0.00126 & $\begin{array}{c}0.080 \\
27\end{array}$ & $\begin{array}{c}0.125 \\
12\end{array}$ & $\begin{array}{c}0.236 \\
44\end{array}$ & $\begin{array}{c}0.216 \\
71\end{array}$ & $\begin{array}{c}0.016 \\
17\end{array}$ & $\begin{array}{c}0.011 \\
48\end{array}$ & $\begin{array}{c}0.004 \\
93\end{array}$ & $\begin{array}{c}0.002 \\
84\end{array}$ & $\begin{array}{c}0.002 \\
59\end{array}$ & $\begin{array}{c}0.000 \\
00\end{array}$ & $\begin{array}{c}0.021 \\
75\end{array}$ & $\begin{array}{c}0.010 \\
41\end{array}$ & $\begin{array}{c}0.000 \\
00\end{array}$ & $\begin{array}{c}0.000 \\
00\end{array}$ \\
\hline $4 M$ & $\begin{array}{c}0.0023 \\
2\end{array}$ & 0.00144 & $\begin{array}{c}0.122 \\
13\end{array}$ & $\begin{array}{c}0.035 \\
14\end{array}$ & $\begin{array}{c}0.125 \\
07\end{array}$ & $\begin{array}{c}0.079 \\
45\end{array}$ & $\begin{array}{c}0.104 \\
06\end{array}$ & $\begin{array}{c}0.064 \\
87\end{array}$ & $\begin{array}{c}0.012 \\
99\end{array}$ & $\begin{array}{c}0.002 \\
33\end{array}$ & $\begin{array}{c}0.003 \\
31\end{array}$ & $\begin{array}{c}0.000 \\
00\end{array}$ & $\begin{array}{c}0.017 \\
86\end{array}$ & $\begin{array}{c}0.058 \\
63\end{array}$ & $\begin{array}{c}0.000 \\
00\end{array}$ & $\begin{array}{c}0.000 \\
00\end{array}$ \\
\hline $5 M$ & $\begin{array}{c}0.0057 \\
2\end{array}$ & 0.00313 & $\begin{array}{c}0.210 \\
96\end{array}$ & $\begin{array}{c}0.079 \\
56\end{array}$ & $\begin{array}{c}0.068 \\
01\end{array}$ & $\begin{array}{c}0.140 \\
31\end{array}$ & $\begin{array}{c}0.017 \\
99\end{array}$ & $\begin{array}{c}0.015 \\
11\end{array}$ & $\begin{array}{c}0.010 \\
35\end{array}$ & $\begin{array}{c}0.007 \\
29\end{array}$ & $\begin{array}{c}0.006 \\
35\end{array}$ & $\begin{array}{c}0.000 \\
00\end{array}$ & $\begin{array}{c}0.055 \\
90\end{array}$ & $\begin{array}{c}0.013 \\
75\end{array}$ & $\begin{array}{c}0.000 \\
00\end{array}$ & $\begin{array}{c}0.000 \\
00\end{array}$ \\
\hline $6 \mathrm{M}$ & $\begin{array}{c}0.0061 \\
8\end{array}$ & 0.00339 & $\begin{array}{c}0.189 \\
51\end{array}$ & $\begin{array}{c}0.122 \\
32\end{array}$ & $\begin{array}{c}0.228 \\
99\end{array}$ & $\begin{array}{c}0.066 \\
04\end{array}$ & $\begin{array}{c}0.022 \\
95\end{array}$ & $\begin{array}{c}0.018 \\
45\end{array}$ & $\begin{array}{c}0.011 \\
50\end{array}$ & $\begin{array}{c}0.007 \\
85\end{array}$ & $\begin{array}{c}0.006 \\
88\end{array}$ & $\begin{array}{c}0.000 \\
00\end{array}$ & $\begin{array}{c}0.060 \\
22\end{array}$ & $\begin{array}{c}0.016 \\
77\end{array}$ & $\begin{array}{c}0.000 \\
00\end{array}$ & $\begin{array}{c}0.000 \\
00\end{array}$ \\
\hline $7 D$ & $\begin{array}{c}0.0086 \\
7\end{array}$ & 0.00569 & $\begin{array}{c}0.007 \\
92\end{array}$ & $\begin{array}{c}0.056 \\
18\end{array}$ & $\begin{array}{c}0.008 \\
37\end{array}$ & $\begin{array}{c}0.012 \\
10\end{array}$ & $\begin{array}{c}0.032 \\
84\end{array}$ & $\begin{array}{c}0.112 \\
86\end{array}$ & $\begin{array}{c}0.064 \\
30\end{array}$ & $\begin{array}{c}0.007 \\
55\end{array}$ & $\begin{array}{c}0.013 \\
67\end{array}$ & $\begin{array}{c}0.000 \\
00\end{array}$ & $\begin{array}{c}0.057 \\
90\end{array}$ & $\begin{array}{c}0.070 \\
31\end{array}$ & $\begin{array}{c}0.000 \\
00\end{array}$ & $\begin{array}{c}0.000 \\
00\end{array}$ \\
\hline 8D & $\begin{array}{c}0.0072 \\
6\end{array}$ & 0.00566 & $\begin{array}{c}0.002 \\
82\end{array}$ & $\begin{array}{c}0.019 \\
53\end{array}$ & $\begin{array}{c}0.002 \\
99\end{array}$ & $\begin{array}{c}0.004 \\
61\end{array}$ & $\begin{array}{c}0.110 \\
00\end{array}$ & $\begin{array}{c}0.032 \\
89\end{array}$ & $\begin{array}{c}0.099 \\
85\end{array}$ & $\begin{array}{c}0.003 \\
01\end{array}$ & $\begin{array}{c}0.015 \\
27\end{array}$ & $\begin{array}{c}0.000 \\
00\end{array}$ & $\begin{array}{c}0.023 \\
06\end{array}$ & $\begin{array}{c}0.107 \\
14\end{array}$ & $\begin{array}{c}0.000 \\
00\end{array}$ & $\begin{array}{c}0.000 \\
00\end{array}$ \\
\hline 9D & $\begin{array}{c}0.0680 \\
8\end{array}$ & 0.05541 & $\begin{array}{c}0.006 \\
22\end{array}$ & $\begin{array}{c}0.023 \\
84\end{array}$ & $\begin{array}{c}0.007 \\
05\end{array}$ & $\begin{array}{c}0.022 \\
40\end{array}$ & $\begin{array}{c}0.105 \\
77\end{array}$ & $\begin{array}{c}0.103 \\
73\end{array}$ & $\begin{array}{c}0.055 \\
68\end{array}$ & $\begin{array}{c}0.019 \\
67\end{array}$ & $\begin{array}{c}0.153 \\
22\end{array}$ & $\begin{array}{c}0.000 \\
00\end{array}$ & $\begin{array}{c}0.150 \\
77\end{array}$ & $\begin{array}{c}0.126 \\
12\end{array}$ & $\begin{array}{c}0.000 \\
00\end{array}$ & $\begin{array}{c}0.000 \\
00\end{array}$ \\
\hline 10D & $\begin{array}{c}0.0093 \\
8\end{array}$ & 0.00511 & $\begin{array}{c}0.002 \\
60\end{array}$ & $\begin{array}{c}0.004 \\
31\end{array}$ & $\begin{array}{c}0.003 \\
08\end{array}$ & $\begin{array}{c}0.012 \\
93\end{array}$ & $\begin{array}{c}0.017 \\
32\end{array}$ & $\begin{array}{c}0.017 \\
37\end{array}$ & $\begin{array}{c}0.015 \\
86\end{array}$ & $\begin{array}{c}0.012 \\
03\end{array}$ & $\begin{array}{c}0.010 \\
31\end{array}$ & $\begin{array}{c}0.000 \\
00\end{array}$ & $\begin{array}{c}0.092 \\
21\end{array}$ & $\begin{array}{c}0.015 \\
86\end{array}$ & $\begin{array}{c}0.000 \\
00\end{array}$ & $\begin{array}{c}0.000 \\
00\end{array}$ \\
\hline 11D & $\begin{array}{c}0.0535 \\
2\end{array}$ & 0.00987 & $\begin{array}{c}0.001 \\
62\end{array}$ & $\begin{array}{c}0.008 \\
86\end{array}$ & $\begin{array}{c}0.001 \\
78\end{array}$ & $\begin{array}{c}0.004 \\
18\end{array}$ & $\begin{array}{c}0.108 \\
60\end{array}$ & $\begin{array}{c}0.068 \\
46\end{array}$ & $\begin{array}{c}0.147 \\
76\end{array}$ & $\begin{array}{c}0.003 \\
36\end{array}$ & $\begin{array}{c}0.021 \\
94\end{array}$ & $\begin{array}{c}0.000 \\
00\end{array}$ & $\begin{array}{c}0.025 \\
73\end{array}$ & $\begin{array}{c}0.027 \\
26\end{array}$ & $\begin{array}{c}0.000 \\
00\end{array}$ & $\begin{array}{c}0.000 \\
00\end{array}$ \\
\hline $12 \mathrm{E}$ & $\begin{array}{c}0.0000 \\
0\end{array}$ & 0.00000 & $\begin{array}{c}0.000 \\
00\end{array}$ & $\begin{array}{c}0.000 \\
00\end{array}$ & $\begin{array}{c}0.000 \\
00\end{array}$ & $\begin{array}{c}0.000 \\
00\end{array}$ & $\begin{array}{c}0.000 \\
00\end{array}$ & $\begin{array}{c}0.000 \\
00\end{array}$ & $\begin{array}{c}0.000 \\
00\end{array}$ & $\begin{array}{c}0.000 \\
00\end{array}$ & $\begin{array}{c}0.000 \\
00\end{array}$ & $\begin{array}{c}0.031 \\
19\end{array}$ & $\begin{array}{c}0.000 \\
00\end{array}$ & $\begin{array}{c}0.000 \\
00\end{array}$ & $\begin{array}{c}0.179 \\
34\end{array}$ & $\begin{array}{c}0.000 \\
00\end{array}$ \\
\hline
\end{tabular}




\begin{tabular}{|c|c|c|c|c|c|c|c|c|c|c|c|c|c|c|c|c|}
\hline $13 E$ & $\begin{array}{c}0.1078 \\
5 \\
\end{array}$ & 0.05872 & $\begin{array}{c}0.029 \\
86 \\
\end{array}$ & $\begin{array}{c}0.049 \\
51 \\
\end{array}$ & $\begin{array}{c}0.035 \\
36\end{array}$ & $\begin{array}{c}0.148 \\
73 \\
\end{array}$ & $\begin{array}{c}0.199 \\
19 \\
\end{array}$ & $\begin{array}{c}0.199 \\
76 \\
\end{array}$ & $\begin{array}{c}0.182 \\
36 \\
\end{array}$ & $\begin{array}{c}0.138 \\
31 \\
\end{array}$ & $\begin{array}{c}0.118 \\
55 \\
\end{array}$ & $\begin{array}{c}0.000 \\
00 \\
\end{array}$ & $\begin{array}{c}0.060 \\
41 \\
\end{array}$ & $\begin{array}{c}0.182 \\
36 \\
\end{array}$ & $\begin{array}{c}0.000 \\
00 \\
\end{array}$ & $\begin{array}{c}0.000 \\
00 \\
\end{array}$ \\
\hline $14 E$ & $\begin{array}{c}0.0066 \\
9\end{array}$ & 0.00397 & $\begin{array}{c}0.018 \\
28\end{array}$ & $\begin{array}{c}0.144 \\
60\end{array}$ & $\begin{array}{c}0.018 \\
97\end{array}$ & $\begin{array}{c}0.018 \\
48\end{array}$ & $\begin{array}{c}0.126 \\
39\end{array}$ & $\begin{array}{c}0.161 \\
69\end{array}$ & $\begin{array}{c}0.028 \\
24\end{array}$ & $\begin{array}{c}0.007 \\
37\end{array}$ & $\begin{array}{c}0.008 \\
77\end{array}$ & $\begin{array}{c}0.000 \\
00\end{array}$ & $\begin{array}{c}0.056 \\
48\end{array}$ & $\begin{array}{c}0.035 \\
66\end{array}$ & $\begin{array}{c}0.000 \\
00\end{array}$ & $\begin{array}{c}0.000 \\
00\end{array}$ \\
\hline $15 E$ & $\begin{array}{c}0.0000 \\
0\end{array}$ & 0.00000 & $\begin{array}{c}0.000 \\
00\end{array}$ & $\begin{array}{c}0.000 \\
00\end{array}$ & $\begin{array}{c}0.000 \\
00\end{array}$ & $\begin{array}{c}0.000 \\
00\end{array}$ & $\begin{array}{c}0.000 \\
00\end{array}$ & $\begin{array}{c}0.000 \\
00\end{array}$ & $\begin{array}{c}0.000 \\
00\end{array}$ & $\begin{array}{c}0.000 \\
00\end{array}$ & $\begin{array}{c}0.000 \\
00\end{array}$ & $\begin{array}{c}0.179 \\
34\end{array}$ & $\begin{array}{c}0.000 \\
00\end{array}$ & $\begin{array}{c}0.000 \\
00\end{array}$ & $\begin{array}{c}0.031 \\
19\end{array}$ & $\begin{array}{c}0.000 \\
00\end{array}$ \\
\hline $16 \mathrm{E}$ & $\begin{array}{c}0.0000 \\
0\end{array}$ & 0.00000 & $\begin{array}{c}0.000 \\
00\end{array}$ & $\begin{array}{c}0.000 \\
00\end{array}$ & $\begin{array}{c}0.000 \\
00\end{array}$ & $\begin{array}{c}0.000 \\
00\end{array}$ & $\begin{array}{c}0.000 \\
00\end{array}$ & $\begin{array}{c}0.000 \\
00\end{array}$ & $\begin{array}{c}0.000 \\
00\end{array}$ & $\begin{array}{c}0.000 \\
00\end{array}$ & $\begin{array}{c}0.000 \\
00\end{array}$ & $\begin{array}{c}0.000 \\
00\end{array}$ & $\begin{array}{c}0.000 \\
00\end{array}$ & $\begin{array}{c}0.000 \\
00\end{array}$ & $\begin{array}{c}0.000 \\
00\end{array}$ & $\begin{array}{c}0.000 \\
00\end{array}$ \\
\hline
\end{tabular}

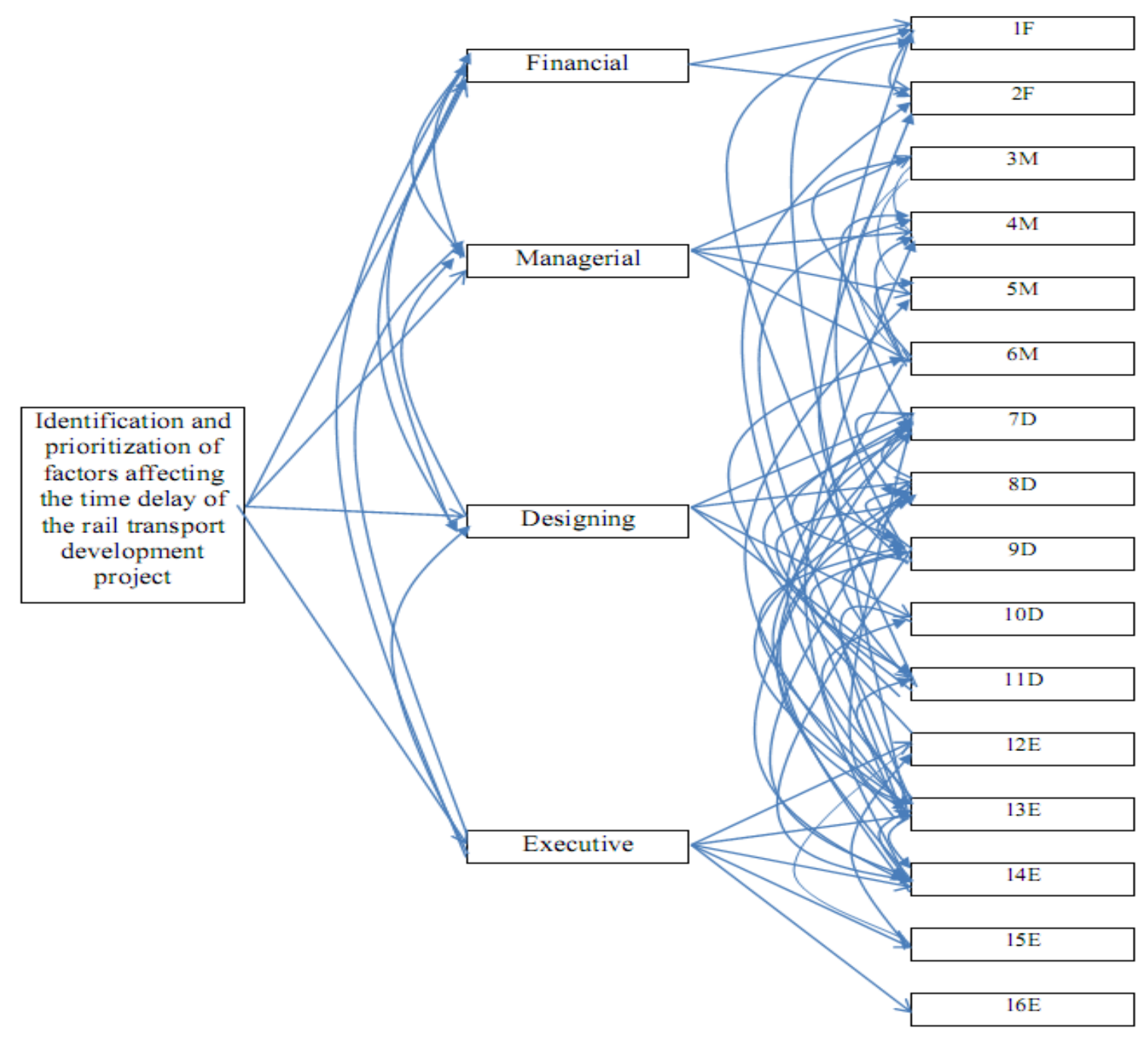

Figure 2: Network's internal interactions and connections

\subsection{Evaluation the effective factors on delays in rail transportation projects}

In this study, ANP Method was used to evaluate the effective factors on delays in rail transportation development projects in MSC. In order to solve this problem, a network was created where the nodes indicated that the required goals, factors or options and vectors connecting these nodes are indicating the existence and direction of effects between each two nodes. In the modeling stage, the decision-making's goal, its factors and possible options are specified. Using pairwise comparison, it is possible to determine the relative weight of factors and sub-factors. The pairwise comparison of elements at each level is carried out based on 
their relative importance compared to control criteria, which is similar to hierarchical approach (Khademi et al., 2011; Asadabadi et al. 2019). In these comparisons, a relative value of 1 to 9 is assigned in order to compare each two elements (Table 6).

Table 6: The valuation for pairwise comparison based on degree of importance (Saati, 1980).

\begin{tabular}{|c|c|c|}
\hline Value & Priority & Description \\
\hline 1 & Similar & Option or factor $\mathrm{i}$ has similar priority compared to $\mathrm{j}$ \\
\hline 3 & Small priority & Option or factor i has slightly higher priority compared to j \\
\hline 5 & Higher priority & Option or factor $\mathrm{i}$ has higher priority compared to $\mathrm{j}$ \\
\hline 7 & $\begin{array}{l}\text { Significantly higher } \\
\text { priority }\end{array}$ & Option or factor i has significantly higher priority compared to $\mathrm{j}$ \\
\hline 9 & Fully preferred & Option or factor $\mathrm{i}$ is fully preferred and can't be compared to $\mathrm{j}$ \\
\hline $2,4,6,8$ & Intermediate & $\begin{array}{l}\text { Show values between preferred values. For example, a score of } 8 \\
\text { shows higher priority compared to } 7 \text { and lower priority than } 9 \text { for } i\end{array}$ \\
\hline
\end{tabular}

Also, the internal weights of factors and sub-factors (specified during modeling step) are calculated as well as the considerations of the, internal dependencies and feedbacks. The important point in pairwise judgments and comparisons is to control for compatibility. This is especially important in macro decisions because people might act contradictory in their judgments. In general, a compatibility of less than 0.1 in pairwise comparison matrix is acceptable. Compatibility ratio $(\mathrm{CR})$ for each matrix is calculated where $\mathrm{Cl}$ is the compatibility index o pairwise comparison matrix calculated based on highest Eigen vector value $\left(\lambda_{\operatorname{Max}}\right)$ and its dimension ( $n$ ). The compatibility rate is calculated by the software and presented for each pairwise comparison matrix. If this value exceeds 0.1 , then the judgment is incompatible and the method of judgment must be revised (Son,2014; Ortiz et al. 2015; Asadabadi et al. 2019).

One of the calculation methods for ANP is to put the weights calculated in pairwise comparisons in a super matrix. This super matrix is a matrix of relations between network members which is calculated using Eigen vectors of these relations. Super matrix can be divided into various blocks. Each block shows the weights calculated through pairwise comparisons of rows (i.e. factors) based on columns (i.e. options). After the formation of the initial super matrix, which is known as Inharmonious super matrix, if necessary, the columns in this matrix are normalized and a weighted or normalized super matrix is calculated. Saati used probability matrices and Markov chains to prove that the final weight is calculated using equation 10 (Asadabadi et al. 2019)

$W=\lim _{k \rightarrow \infty} w^{2 k+1} \pi r^{2}$

Where $\mathrm{k}$ is an odd number. Solving the above equation results in the final matrix or the constrained matrix. In this matrix, the elements in each row are equal to each other and to the weight determined for that row. 
In this study, DEMATEL method is used only for analysing and quantifying cause-effect relationships, in order to simplify network relationships. ANP is used to evaluate weights of the business environment criteria in order to prioritize and evaluate the interactions between these delay factors. So, different scales of ANP (scale of 1-9) and DEMATEL (scale of 0-4 or 1-5) does not affect the results. Selection scales for ANP (scale of 1-9) and DEMATEL (scale of 0-4 or 1-5) has been done based on past researches (Saati, 1980; Khademi et al., 2011; Kaushik, 2015; Büyüközkan \& Çifçi, 2016; Asadabadi et al. 2019).

\subsubsection{The result of data analysis using Analytic Network Process}

The target population in this study included 20 experts involved in rail transportation development projects of MSC who were asked to fill the questionnaire (pairwise comparisons) created based on ANP. The decision-making process when using ANP includes four steps of modeling and structuring, pairwise comparisons of priority vectors, creation of super matrix and final categorization.

The decision tree presented in Figure 2 is simulated in Super Decision software. Then, date is entered into the Super Decision environment for analysis using ANP based on interactions and relations shown in Figure 2. In this study, the inconsistency rate lower than 0.1 for all pairwise comparisons are considered as acceptable.

In order to determine the overall priorities in a system with internal interactions, internal priority vectors are entered in the columns of a matrix. Therefore, a super matrix (a divided matrix) is created where each part of the matrix shows the relationships between two clusters of the system. The inharmonious super matrix is created by substituting the internal priority vectors of elements and clusters in the initial super matrix. The inharmonious super matrix is presented in Appendix A. In the next step, normalized (harmonious) super matrix is created by multiplying the inharmonious super matrix with the cluster matrix. Harmonious super matrix and limited super matrix are shown in Appendices $C$ and $D$, respectively.

The rankings obtained using Super Decision software for four factors of financial, management, design, and executive are presented in Table 7. Based on these results, management factor plays the largest role in delays of rail transportation development projects in MSC. Factors with second to fourth rankings include financial, executive and design factors, respectively. After evaluating the priority of factors, the final prioritization for sub-factors (delay factors) is presented using Super Decision software. The final ranking matrix is presented in Table 8 while the final prioritization of sub-factors is presented in Table 9. 
Table 7: factor rankings

\begin{tabular}{cccc}
\hline Row & Group & Normalized & Idealized \\
\hline 1 & Financial & 0.2807 & 0.5293 \\
2 & Management & 0.5304 & 1.0000 \\
3 & Design & 0.1361 & 0.2566 \\
4 & Executive & 0.0527 & 0.09937 \\
\hline
\end{tabular}

Table 8: Final ranking matrix

\begin{tabular}{cccc}
\hline Name & Ideals & Normals & Raw \\
\hline $1 \mathrm{~F}$ & 0.297731 & 0.060966 & 0.060966 \\
$2 \mathrm{~F}$ & 0.342820 & 0.070199 & 0.070199 \\
$3 \mathrm{M}$ & 0.853110 & 0.174691 & 0.174691 \\
$4 \mathrm{M}$ & 1.000000 & 0.204770 & 0.204770 \\
$5 \mathrm{M}$ & 0.571159 & 0.116956 & 0.116956 \\
$6 \mathrm{M}$ & 0.454642 & 0.093097 & 0.093097 \\
$7 \mathrm{D}$ & 0.484989 & 0.099311 & 0.099311 \\
$8 \mathrm{D}$ & 0.406127 & 0.083162 & 0.083162 \\
$9 \mathrm{D}$ & 0.080787 & 0.016543 & 0.016543 \\
$10 \mathrm{D}$ & 0.017548 & 0.003593 & 0.003593 \\
$11 \mathrm{D}$ & 0.055581 & 0.011381 & 0.011381 \\
$12 \mathrm{E}$ & 0.019046 & 0.003900 & 0.003900 \\
$13 \mathrm{E}$ & 0.123999 & 0.025391 & 0.025391 \\
$14 \mathrm{E}$ & 0.156947 & 0.032138 & 0.032138 \\
$15 \mathrm{E}$ & 0.019046 & 0.003900 & 0.003900 \\
$16 \mathrm{E}$ & 0.000000 & 0.000000 & 0.000000 \\
\hline
\end{tabular}

Table 9: Final ranking of delay sub-factors

\begin{tabular}{ll}
\hline \multicolumn{1}{c}{ Sub-factor } & \multicolumn{1}{c}{ Code } \\
\hline Lack of budget predictions for new activities \\
in contracts \\
Lack of transparency in general and specific \\
contract conditions of MSC \\
$\begin{array}{l}\text { Lack of central role for project lead in } \\
\text { execution stages (scattering of decision- } \\
\text { makers in projects) }\end{array}$
\end{tabular}




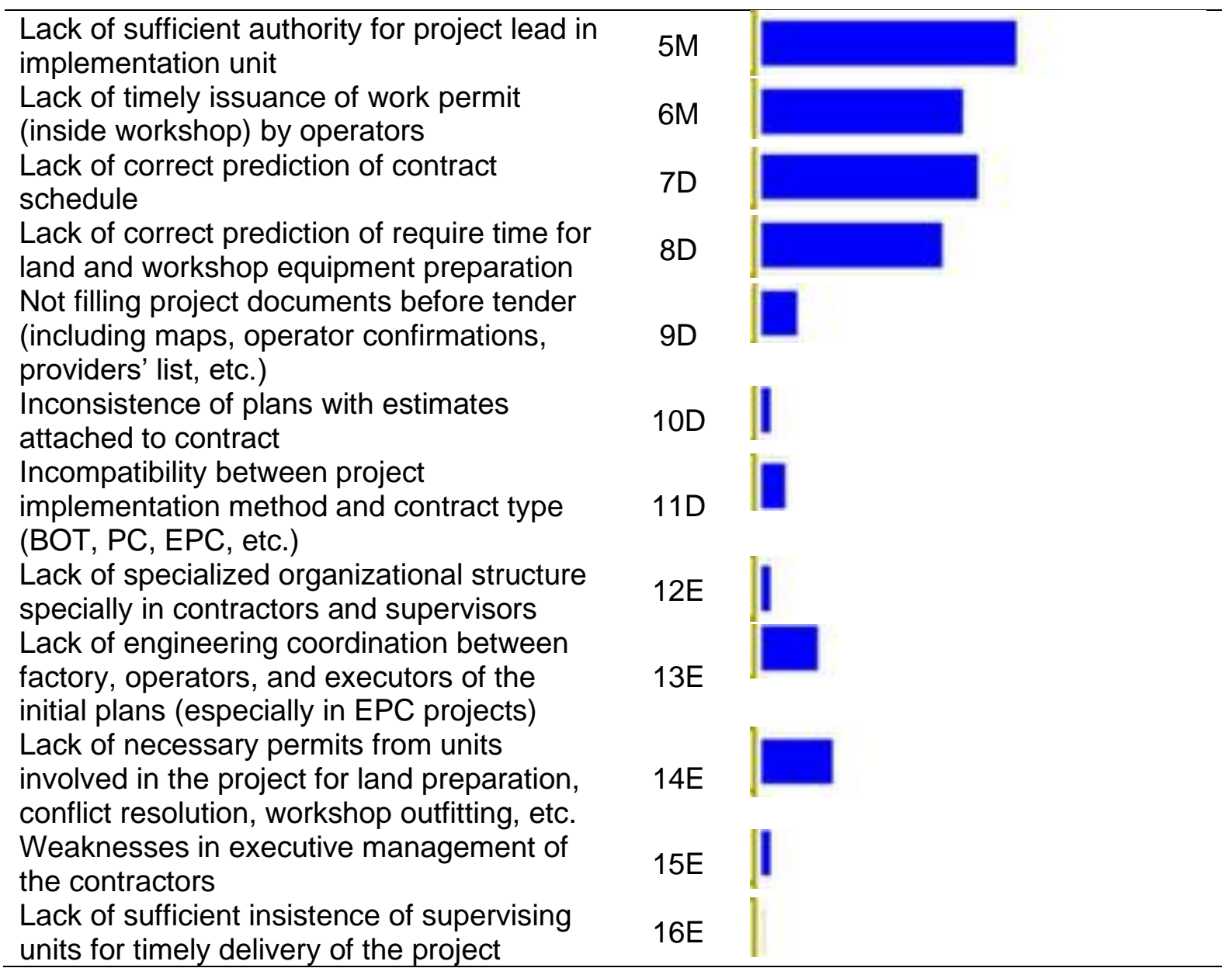

\subsection{The final ranking of delay sub-factors}

The final ranking for factors affecting delays of rail transportation development projects in MSC were determined based on the weights of factors and sub-factors using ANP method in decreasing order. Among the four main factors identified in this study, management factor had the highest weight and the first rank and was the most important reason for delays of rail transportation development projects in MSC. A similar study by Pall et al. (2019) which investigated project delay factors in a heavy engineering sector, shows the management factor is critical to the project meeting its target schedule. Accordingly, they recommended the employers to work in harmony with other stakeholders such as the contractors, consultants, etc. to streamline all the contractual and other project processes. Furthermore, financial factor was in the second place, design factor was in the third place and executive factor was in the fourth place (see Table 5). Similar findings were revealed in the study by El-Kholy (2019) and Mahdi and Soliman (2018).

Regarding the sub-factors for each main factor - the final ranking was carried out according to Table 6 and sub-factors of numerous decision-making points in the project (outside of implementation deputy) had the first rank and was the most important reason for delays in rail 
transportation development projects in MSC. Furthermore, sub-factors of lack of central role for project manager during implementation phase (the scattering of decision-makers in the project) had was the second most important sub-factor and lack of sufficient authority for project manager was the third important factor among a total of 16 identified sub-factors causing delays in rail transportation development projects in MSC. The sub-factor 16E - "lack of sufficient insistence of supervising units for timely delivery of the project" has the lowest weighting and rank has no influence on project delays in railway transportation.

\section{Conclusions}

This study aimed at identifying and prioritizing the reasons for delays in rail transportation development projects in MSC in Iran using the ANP approach. The results showed that among the four identified main factor categories, the management factor had the highest weight hence must be given the first priority in decision-making towards preventing delays in rail transportation development projects. Financial, design, and executive actors were located in the second to fourth places, respectively.

Moreover, among the sub-factors, numerous decision-making points in the project (outside of implementation deputy) had the first rank among factors causing delays in rail transportation development projects in MSC. Furthermore, the sub-factor of lack of a central role for project manager during the implementation phase was ranked in the second place while lack of sufficient authority for the project manager was in the third place, all of which subsumed to the management factor. This shows that alleviating problems with the management domain can significantly avoid or mitigate delays in rail transportation development projects.

The current study is limited in scope because respondents are from a single organization the Mobarakeh Steel Complex; although, MSC is the largest steel manufacturer in the Middle East. Also, a small sample size of respondents was involved, however, their experience in railway transportation compensated for this limitation. Future studies can undertake similar studies in other regions, countries, or construction organizations towards ameliorating the impacts of project delays in railway constructions. The study's findings and recommendations can serve as a policy and consultative instrument for the relevant stakeholders in the railway industry. 


\section{References}

Adam A, Josephson P-E, \& Lindahl G. (2015), Implications of Cost Overruns and Time Delays on Major Public Construction Projects, Proceedings of the 19th International Symposium on Advancement of Construction Management and Real Estate (pp.747758), DOI: 10.1007/978-3-662-46994-1_61

Aldagheiri M, (2010). The expected role of railways in the economic development of Saudi Arabia. WIT Transactions on the Built Environment, 111: 157-167. DOI:10.2495/UT100151

Anbarzadeh, S. R, Azadi, S, \& Jouharian, J. (2019), Identification and Prioritization of Causes of Delay in Kermanshah Train Project Using AHP and Fuzzy TOPSIS Combined method, 2nd International Conference on Industrial Management and Engineering in New Era, Tehran - Industrial Management Conference. https://www.civilica.com/Paper-IEMCONF02-IEMCONF02_050.html (In Persian)

Asadabadi, M. R., Chang, E., \& Saberi, M. (2019). Are MCDM methods useful? A critical review of Analytic Hierarchy Process (AHP) and Analytic Network Process (ANP). Cogent Engineering, 6(1), 1623153. DOI: 10.1080/23311916.2019.1623153

Aswathi R, \& Thomas C. (2013). Development of a Delay Analysis System for a railway construction Project. International Journal of Innovative Research in Science. Engineering and Technology. 2(1):531-541.

Behbahani H, Yaghoubi H, \& Rezvani MA. (2012), Development of Technical and Economical models for widespread application of magnetic levitation system in public transport, International Journal of Civil Engineering, 1(1): 14-24.

Brady S.R (2015), Utilizing and Adapting the Delphi Method for Use in Qualitative Research, International Journal of Qualitative Methods, 14(5): 1-6. DOI: $10.1177 / 1609406915621381$

Büyüközkan, G., \& Güleryüz, S. (2016), An integrated DEMATEL-ANP approach for renewable energy resources selection in Turkey, International Journal of Production Economics, 182: 435-448. DOI: 10.1016/j.ijpe.2016.09.015

Chadwick B.A., Bahr H.M., \& Albrecht S.L. (1984). Social science research methods, Prentice-Hall, EnglewoodCliffs.

Chan, A.P.C., Lam, P.T.I., Wen, Y., Ameyaw, E.E., Wang, S., \& Ke, Y. (2015). CrossSectional analysis of critical risk factors for PPP water projects in China. Journal of Infrastructure Systems, 21(1), 4014031. http://dx.doi.org/10.1061/(ASCE)IS.1943-555X.0000214

Chan, D.W.M., \& Chan, J.H.L. (2012). Developing a performance measurement index (PMI) for target cost contracts in construction: A delphi study. Construction Law Journal (CLJ), 28(8), 590-613. Retrieved from http://repository.lib.polyu.edu.hk/jspui/handle/10397/5364

Cheng, E.W.L., Li, H.(2005). Analytic Network Process Applied to Project Selection. Journal of Construction Engineering and Management, 131(4): DOI: https://doi.org/10.1061/(ASCE)0733-9364(2005)131:4(459)

Cigu, E., Agheorghiesei D.A., Gavrilut A.F., \& Toader E. (2019), Transport Infrastructure Development, Public Performance and Long-Run Economic Growth: A Case Study for the Eu-28 Countries, Sustainability, 11, 67; DOI:10.3390/su11010067

Cyril, O., Oyelaran O.A., Daniel, A., \& Agbo N. (2017), The Steel Industry: A Stimulus to National Development, Journal of Powder Metallurgy \& Mining, 6(1): 1000156. DOI: 10.4172/2168-9806.1000156 
Dedasht. G., Mohamad Zin, R., Salim Ferwati, M., Mohammed Abdullahi, M., Keyvanfar, A., McCaffer R. (2017). DEMATEL-ANP Risk Assessment in Oil and Gas Construction Projects. Sustainability. 9, 1420; DOI: 10.3390/su9081420

El-Kholy, A. M. (2019): Exploring the best ANN model based on four paradigms to predict delay and cost overrun percentages of highway projects, International Journal of Construction Management. DOI: 10.1080/15623599.2019.1580001

Fadavi-Ghaffari, M., Azad, A., Shariatzadeh, H., Taghizadeh, G., \& Aminizadeh, S. (2017). Translation, Cultural Adaptation, Face and Content Validity of the Persian Version "Patient-Rated Wrist Evaluation" (PRWE-Persian) Questionnaire. Journal of Modern Rehabilitation, 11(1) 51-62. DOI: 10.18869/nirp.jmr.11.1.51

Han, S. H., Yun, S., Kim, H., Kwak, Y. H., Park, H. K., \& Lee, S. H. (2009). Analyzing Schedule Delay of Mega Project: Lessons Learned from Korea Train Express. IEEE Transactions on Engineering Management. 56(2): 243-256. DOI: 10.1109/TEM.2009.2016042

Hassanzadeh, R.N., Allahyari, T., Khosravi, Y., Zaeri, F., \& Saremi, M. (2012). Development of an Occupational Cognitive Failure Questionnaire (OCFQ): Evaluation validity and reliability, Iran Occupational Health, 9 (1): 29-40 (In Persian)

Hughes, S.W., Tippett, D.D., Thomas, W.K. (2015), Measuring Project Success in the Construction Industry, Engineering Management Journal; EMJ 16(3):31-37. DOI: 10.1080/10429247.2004.11415255

Ji, Y.,Qi, L., Liu, Y., Liu, X. ,Li, H.X.,Li Y. (2018). Assessing and Prioritising Delay Factors of Prefabricated Concrete Building Projects in China. Applied Sciences. 8(11), 2324; https://doi.org/10.3390/app8112324

Kaushik, S. (2015). DEMATEL: A Methodology for Research in Library and Information Science, International Journal of Librarianship and Administration, 6(2), pp. 179-185.

Karamoozian, A., Wu, D., Chen C.L.P., Luo C. (2019). An Approach for Risk Prioritization in Construction Projects Using Analytic Network Process and Decision Making Trial and Evaluation Laboratory. IEEE Access. 7:159842-159854. https://doi.org/10.1109/ACCESS.2019.2939067

Khademi, N., Mohaymany, A.S., Shahi, J., \& Zerguini, S. (2011). An Algorithm for the Analytic Network Process (ANP) Structure Design, Journal of Multi-Criteria Decision Analysis (JMCDA), 19(2):33-55. DOI:10.1002/mcda.485

Lawshe, C.H. (1975). A quantitative approach to content validity. Personnel Psychology, 28: 563-575.

Mahdi, I., \& Soliman, E. (2018). Significant and top ranked delay factors in Arabic Gulf countries, International Journal of Construction Management. DOI: $10.1080 / 15623599.2018 .1512029$

Mittal, Y.K., \& Paul V.K. (2018). Identification of critical factors for delay in metro rail projects in India. International Journal of Students' Research in Technology \& Management. 6(1):30-39. DOI: 10.18510/ijsrtm.2018.615

Mohri, S., \& Haghshenas, H. (2017), Evaluation of Iran Rail Freight Transportation Efficiency in Comparison between the World Countries and the Middle East and Central Asia, International Journal of Transportation Engineering, 5(2):103-117. DOI:10.22119/IJTE.2017.46512

Nikjou, M.A., Kiani, M., \& Nurang, A., (2009), Knowledge Management Investigating the Causes of Delay in Tabriz Urban Train Line EPC Project 2 Using the Decision Tree Tool, 1th National EPC Project Implementation Conference, Tehran, Contracting 
System Study Group, https: //www.civilica.com/Paper-EPC01-EPC01_008.html (In Persian)

Oktavia, R., Rajibussalim, I., Mentari, M., \& Mulia, I.S, (2018), Assessing the validity and reliability of questionnaires on the implementation of Indonesian curriculum K-13 in STEM education, IOP Conf. Series: Journal of Physics: Conf. Series 1088, 012014 DOI: :10.1088/1742-6596/1088/1/012014

Olawumi, T.O., \& Chan, D.W.M. (2018). Identifying and Prioritizing the Benefits of Integrating BIM and Sustainability Practices in Construction Projects: A Delphi Survey of International Experts. Sustainable Cities and Society, 40, 16-27. https://doi.org/10.1016/..scs.2018.03.033

Olawumi, T.O., Chan, D.W.M., Wong, J.K.W., \& Chan, A.P.C (2018). Barriers to the Integration of BIM and Sustainability Practices in Construction Projects: A Delphi Survey of International Experts. Journal of Building Engineering, 20, 60-71. https://doi.org/10.1016/j.jobe.2018.06.017

Ortíz, M. A., Felizzola, H. A., \& Isaza, S. N. (2015). A contrast between DEMATEL-ANP and ANP methods for six sigma project selection: a case study in healthcare industry. BMC medical informatics and decision making, 15(S3), S3.. DOI: 10.1186/1472-6947-15S3-S3

Pall, G.K., Bridge, A.J., Washington, S., Gray, J., \& Skitmore, M. (2019): Critical delay factors in power transmission projects: a structural equation modeling approach, International Journal of Construction Management. DOI: 10.1080/15623599.2019.1686835

Pezshki, Z.M., Shadman, A., Alizadeh, M, Hakimi., S., \& Heidari, F. (2017), Validity and reliability of the questionnaire for assessing women's reproductive history in Azar cohort study, Journal of Caring Sciences, 6 (2): 185-88. DOI: 10.15171/jcs.2017.018.

Phang, S. (2003), Strategic development of Airport and Rail Infrastructure: The Case of Singapore. Transportation Policy, 10: 27-33.

Sarvari, H., Rakhshanifar, M., Tamošaitienè, J., Chan, D.W.M. \& Beer, M. (2019). A Risk Based Approach to Evaluating the Impacts of Zayanderood Drought on Sustainable Development Indicators of Riverside Urban in Isfahan-Iran, Sustainability - Special Issue on Sustainability and Risks in Construction Management, 11(23): Article Number 6797, 20 pages, DOI: https://doi.org/10.3390/su11236797.

Shafiepour, M., Tamannaei, M., \& Abtahi, S.M. (2018), A Methodology to Prioritize the Construction Projects of New Railway Infrastructures for Privatization in Railway Networks (Case Study: Iran), International Journal of Transportation Engineering, 6(2): 123-143

Sojoodi S., Mohseni Zonuzi F., \& Mehin Aslani Nia N. (2012). The Role of Infrastructure in Promoting Economic Growth in Iran. Iranian Economic Review. 16(32):111-132.

Son L.N. (2014), Consistency Test in ANP Method with Group Judgment Under Intuitionistic Fuzzy Environment, International Journal of Soft Computing and Engineering, 4(3): 6871.

Taber K.S. (2018), The Use of Cronbach's Alpha When Developing and Reporting Research Instruments in Science Education, Research in Science Education. 48:1273-1296. DOI:10.1007/s11165-016-9602-2

VarNaseri, N., \& ShekastehBand, P. (2018), Identifying and Prioritizing the Causes of Delay in the Development of Rail Transport Industry Projects, International Conference on Industrial Management and Engineering in Modern Era, Tehran, Arvin Alborz Conference, https: // www .civilica.com / Paper-IEMCONF01-IEMCONF01_022.html (In Persian) 
Wang, L., Xue, X., Zhao, Z., \& Wang, Z. (2018). The impacts of transportation infrastructure on sustainable development: Emerging trends and challenges. International Journal of Environmental Research and Public Health, 15(6), 1172.

Zanganeh, S. (2016). Investigation of Causes of Delays in Construction of Urban Train Projects of Iran. 11th International Conference and Third National Conference on Construction and Project Management, Tehran, Islamic Azad University, Central Tehran Branch, 7-8 February. https://www.civilica.com/Paper-NCCPM03-NCCPM03_031.html (In Persian) 


\section{Appendix A: weightless super matrix}

\begin{tabular}{|c|c|c|c|c|c|c|c|c|c|c|c|c|c|c|c|c|c|c|c|c|c|c|}
\hline \multirow{2}{*}{\begin{tabular}{|l|} 
\\
어 \\
\end{tabular}} & \multirow[b]{2}{*}{$\begin{array}{l}\text { 0Goal } \\
\text { node }\end{array}$} & \multirow{2}{*}{$\begin{array}{l}\text { 0Goal } \\
\text { 0Goal } \\
\text { node }\end{array}$} & \multicolumn{4}{|c|}{1 Criterias } & \multicolumn{16}{|c|}{ Alternatives } \\
\hline & & & Fin & Man & Des & Exe & $1 \mathrm{~F}$ & $2 \mathrm{~F}$ & $3 \mathrm{M}$ & $4 \mathrm{M}$ & $5 \mathrm{M}$ & $6 \mathrm{M}$ & 7D & 8D & 9D & $10 \mathrm{D}$ & 11D & $12 \mathrm{E}$ & $13 E$ & $14 \mathrm{E}$ & $15 \mathrm{E}$ & $16 \mathrm{E}$ \\
\hline \multirow{4}{*}{ 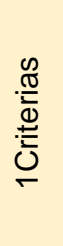 } & Fin & 0.28076 & 0.000 & 0.88889 & 0.14286 & 0.54693 & 0.000 & 0.000 & 0.000 & 0.000 & 0.000 & 0.000 & 0.000 & 0.000 & 0.000 & 0.000 & 0.000 & 0.000 & 0.000 & 0.000 & 0.000 & 0.000 \\
\hline & Man & 0.53042 & 0.33333 & 0.000 & 0.85714 & 0.10853 & 0.000 & 0.000 & 0.000 & 0.000 & 0.000 & 0.000 & 0.000 & 0.000 & 0.000 & 0.000 & 0.000 & 0.000 & 0.000 & 0.000 & 0.000 & 0.000 \\
\hline & Des & 0.13612 & 0.66667 & 0.11111 & 0.000 & 0.34454 & 0.000 & 0.000 & 0.000 & 0.000 & 0.000 & 0.000 & 0.000 & 0.000 & 0.000 & 0.000 & 0.000 & 0.000 & 0.000 & 0.000 & 0.000 & 0.000 \\
\hline & Exe & 0.05271 & 0.000 & 0.000 & 0.000 & 0.000 & 0.000 & 0.000 & 0.000 & 0.000 & 0.000 & 0.000 & 0.000 & 0.000 & 0.000 & 0.000 & 0.000 & 0.000 & 0.000 & 0.000 & 0.000 & 0.000 \\
\hline \multirow{16}{*}{  } & $1 F$ & 0.000 & 0.12500 & 0.000 & 0.000 & 0.000 & 0.000 & 0.53065 & 0.000 & 0.000 & 0.000 & 0.000 & 0.000 & 0.000 & 0.51121 & 0.000 & 0.56754 & 0.000 & 0.34652 & 0.000 & 0.000 & 0.000 \\
\hline & $2 F$ & 0.000 & 0.87500 & 0.000 & 0.000 & 0.000 & 1.00000 & 0.000 & 0.000 & 0.000 & 0.000 & 0.000 & 0.000 & 0.000 & 0.20571 & 0.000 & 0.000 & 0.000 & 0.22961 & 0.000 & 0.000 & 0.000 \\
\hline & $3 \mathrm{M}$ & 0.000 & 0.000 & 0.16116 & 0.000 & 0.000 & 0.000 & 0.000 & 0.000 & 0.33436 & 0.70712 & 0.25266 & 0.000 & 0.000 & 0.000 & 0.000 & 0.000 & 0.000 & 0.000 & 0.000 & 0.000 & 0.000 \\
\hline & $4 \mathrm{M}$ & 0.000 & 0.000 & 0.06754 & 0.000 & 0.000 & 0.000 & 0.000 & 0.71723 & 0.000 & 0.07015 & 0.05115 & 0.48000 & 0.000 & 0.000 & 0.000 & 0.000 & 0.000 & 0.04776 & 0.54848 & 0.000 & 0.000 \\
\hline & $5 \mathrm{M}$ & 0.000 & 0.000 & 0.57333 & 0.000 & 0.000 & 0.000 & 0.000 & 0.08808 & 0.24060 & 0.000 & 0.53488 & 0.000 & 0.000 & 0.000 & 0.000 & 0.000 & 0.000 & 0.09873 & 0.000 & 0.000 & 0.000 \\
\hline & $6 \mathrm{M}$ & 0.000 & 0.000 & 0.19796 & 0.000 & 0.000 & 0.000 & 0.000 & 0.19469 & 0.15656 & 0.22273 & 0.000 & 0.000 & 0.000 & 0.000 & 0.000 & 0.000 & 0.000 & 0.03851 & 0.000 & 0.000 & 0.000 \\
\hline & 7D & 0.000 & 0.000 & 0.000 & 0.08388 & 0.000 & 0.000 & 0.22825 & 0.000 & 0.05123 & 0.000 & 0.000 & 0.000 & 0.74184 & 0.07206 & 0.000 & 0.12634 & 0.000 & 0.03966 & 0.23232 & 0.000 & 0.000 \\
\hline & $8 D$ & 0.000 & 0.000 & 0.000 & 0.03479 & 0.000 & 0.000 & 0.06796 & 0.000 & 0.18875 & 0.000 & 0.000 & 0.28995 & 0.000 & 0.14216 & 0.000 & 0.23557 & 0.000 & .02616 & 0.16333 & 0.000 & 0.000 \\
\hline & 9D & 0.000 & 0.000 & 0.000 & 0.12627 & 0.000 & 0.000 & 0.04055 & 0.000 & 0.000 & 0.000 & 0.000 & 0.05536 & 0.07520 & 0.000 & 0.000 & 0.07055 & 0.000 & 0.04495 & 0.000 & 0.000 & 0.000 \\
\hline & $10 \mathrm{D}$ & 0.000 & 0.000 & 0.000 & 0.28865 & 0.000 & 0.000 & 0.000 & 0.000 & 0.000 & 0.000 & 0.000 & 0.000 & 0.000 & 0.000 & 0.75000 & 0.000 & 0.000 & 0.03538 & 0.000 & 0.000 & 0.000 \\
\hline & 11D & 0.000 & 0.000 & 0.000 & 0.46641 & 0.000 & 0.000 & 0.13259 & 0.000 & 0.000 & 0.000 & 0.000 & 0.000 & 0.000 & 0.02851 & 0.000 & 0.000 & 0.000 & 0.06310 & 0.000 & 0.000 & 0.000 \\
\hline & $12 \mathrm{E}$ & 0.000 & 0.000 & 0.000 & 0.000 & 0.06764 & 0.000 & 0.000 & 0.000 & 0.000 & 0.000 & 0.000 & 0.000 & 0.000 & 0.000 & 0.000 & 0.000 & 0.000 & 0.000 & 0.000 & 1.00000 & 0.000 \\
\hline & $13 E$ & 0.000 & 0.000 & 0.000 & 0.000 & 0.53094 & 0.000 & 0.000 & 0.000 & 0.000 & 0.000 & 0.16132 & 0.07732 & 0.000 & 0.000 & 0.25000 & 0.000 & 0.000 & 0.000 & 0.05587 & 0.000 & 0.000 \\
\hline & $14 \mathrm{E}$ & 0.000 & 0.000 & 0.000 & 0.000 & 0.11590 & 0.000 & 0.000 & 0.000 & 0.02849 & 0.000 & 0.000 & 0.09737 & 0.18296 & 0.04035 & 0.000 & 0.000 & 0.000 & 0.02963 & 0.000 & 0.000 & 0.000 \\
\hline & $15 \mathrm{E}$ & 0.000 & 0.000 & 0.000 & 0.000 & 0.22789 & 0.000 & 0.000 & 0.000 & 0.000 & 0.000 & 0.000 & 0.000 & 0.000 & 0.000 & 0.000 & 0.000 & 1.00000 & 0.000 & 0.000 & 0.000 & 0.000 \\
\hline & $16 \mathrm{E}$ & 0.000 & 0.000 & 0.000 & 0.000 & 0.05762 & 0.000 & 0.000 & 0.000 & 0.000 & 0.000 & 0.000 & 0.000 & 0.000 & 0.000 & 0.000 & 0.000 & 0.000 & 0.000 & 0.000 & 0.000 & 0.000 \\
\hline
\end{tabular}




\section{Appendix B: Network's internal interactions and connections for factors and sub-factors}

Appendix B-1: Network's internal interactions and connections for factors

\begin{tabular}{|c|c|c|c|c|c|c|c|c|c|c|c|c|c|c|c|c|}
\hline & $1 \mathrm{~F}$ & $2 \mathrm{~F}$ & $3 M$ & $4 \mathrm{M}$ & $5 \mathrm{M}$ & $6 \mathrm{M}$ & $7 D$ & $8 D$ & $9 D$ & $10 D$ & $11 \mathrm{D}$ & $12 \mathrm{E}$ & $13 E$ & $14 \mathrm{E}$ & $15 \mathrm{E}$ & $16 \mathrm{E}$ \\
\hline $1 \mathrm{~F}$ & 0 & $\sqrt{ }$ & 0 & 0 & 0 & 0 & 0 & 0 & 0 & 0 & 0 & 0 & 0 & 0 & 0 & 0 \\
\hline $2 \mathrm{~F}$ & $\sqrt{ }$ & 0 & 0 & 0 & 0 & 0 & $\sqrt{ }$ & $\sqrt{ }$ & $\sqrt{ }$ & 0 & $\sqrt{ }$ & 0 & 0 & 0 & 0 & 0 \\
\hline $3 M$ & 0 & 0 & $\sqrt{ }$ & $\sqrt{ }$ & $\sqrt{ }$ & $\sqrt{ }$ & 0 & 0 & 0 & 0 & 0 & 0 & 0 & 0 & 0 & 0 \\
\hline $4 \mathrm{M}$ & 0 & 0 & $\sqrt{ }$ & $\sqrt{ }$ & $\sqrt{ }$ & $\sqrt{ }$ & $\sqrt{ }$ & $\sqrt{ }$ & 0 & 0 & 0 & 0 & 0 & $\sqrt{ }$ & 0 & 0 \\
\hline $5 \mathrm{M}$ & 0 & 0 & $\sqrt{ }$ & $\sqrt{ }$ & $\sqrt{ }$ & $\sqrt{ }$ & 0 & 0 & 0 & 0 & 0 & 0 & 0 & 0 & 0 & 0 \\
\hline $6 \mathrm{M}$ & 0 & 0 & $\sqrt{ }$ & $\sqrt{ }$ & $\sqrt{ }$ & $\sqrt{ }$ & 0 & 0 & 0 & 0 & 0 & 0 & $\sqrt{ }$ & 0 & 0 & 0 \\
\hline $7 \mathrm{D}$ & 0 & 0 & 0 & $\sqrt{ }$ & 0 & 0 & $\sqrt{ }$ & $\sqrt{ }$ & $\sqrt{ }$ & 0 & 0 & 0 & $\sqrt{ }$ & $\sqrt{ }$ & 0 & 0 \\
\hline $8 D$ & 0 & 0 & 0 & 0 & 0 & 0 & $\sqrt{ }$ & $\sqrt{ }$ & $\sqrt{ }$ & 0 & 0 & 0 & 0 & $\sqrt{ }$ & 0 & 0 \\
\hline $9 \mathrm{D}$ & $\sqrt{ }$ & $\sqrt{ }$ & 0 & 0 & 0 & 0 & $\sqrt{ }$ & $\sqrt{ }$ & $\sqrt{ }$ & 0 & $\sqrt{ }$ & 0 & 0 & $\sqrt{ }$ & 0 & 0 \\
\hline $10 \mathrm{D}$ & 0 & 0 & 0 & 0 & 0 & 0 & 0 & 0 & 0 & 0 & 0 & 0 & $\sqrt{ }$ & 0 & 0 & 0 \\
\hline $11 D$ & $\sqrt{ }$ & 0 & 0 & 0 & 0 & 0 & $\sqrt{ }$ & $\sqrt{ }$ & $\sqrt{ }$ & 0 & 0 & 0 & 0 & 0 & 0 & 0 \\
\hline $12 \mathrm{E}$ & 0 & 0 & 0 & 0 & 0 & 0 & 0 & 0 & 0 & 0 & 0 & 0 & 0 & 0 & $\sqrt{ }$ & 0 \\
\hline $13 E$ & $\sqrt{ }$ & $\sqrt{ }$ & 0 & $\sqrt{ }$ & $\sqrt{ }$ & $\sqrt{ }$ & $\sqrt{ }$ & $\sqrt{ }$ & $\sqrt{ }$ & $\sqrt{ }$ & $\sqrt{ }$ & 0 & $\sqrt{ }$ & $\sqrt{ }$ & 0 & 0 \\
\hline $14 \mathrm{E}$ & 0 & 0 & 0 & $\sqrt{ }$ & 0 & 0 & $\sqrt{ }$ & $\sqrt{ }$ & 0 & 0 & 0 & 0 & $\sqrt{ }$ & $\sqrt{ }$ & 0 & 0 \\
\hline $15 \mathrm{E}$ & 0 & 0 & 0 & 0 & 0 & 0 & 0 & 0 & 0 & 0 & 0 & $\sqrt{ }$ & 0 & 0 & 0 & 0 \\
\hline $16 \mathrm{E}$ & 0 & 0 & 0 & 0 & 0 & 0 & 0 & 0 & 0 & 0 & 0 & 0 & 0 & 0 & 0 & 0 \\
\hline
\end{tabular}

\section{Appendix B-2: Network's internal interactions and connections for sub-factors}

\begin{tabular}{|c|c|c|c|}
\hline & Fin & Man & Des \\
\hline Fin & 0 & $\sqrt{ }$ & $\sqrt{ }$ \\
\hline Man & 0 & 0 & $\sqrt{ }$ \\
\hline Des & 0 & $\sqrt{ }$ & $\sqrt{ }$ \\
\hline Exe & 0 & $\sqrt{ }$ & $\sqrt{ }$ \\
\end{tabular}




\section{Appendix C: weighted super matrix}

\begin{tabular}{|c|c|c|c|c|c|c|c|c|c|c|c|c|c|c|c|c|c|c|c|c|c|c|}
\hline \multirow{2}{*}{ 0Goal } & \multirow[b]{2}{*}{$\begin{array}{c}\text { OGoal } \\
\text { node }\end{array}$} & 0Goal & \multicolumn{4}{|c|}{1 Criterias } & \multicolumn{16}{|c|}{ Alternatives } \\
\hline & & $\begin{array}{l}\text { OGoal } \\
\text { node }\end{array}$ & Fin & Man & Des & Exe & $1 \mathrm{~F}$ & $2 \mathrm{~F}$ & $3 \mathrm{M}$ & $4 \mathrm{M}$ & $5 \mathrm{M}$ & $6 \mathrm{M}$ & 7D & $8 \mathrm{D}$ & $9 \mathrm{D}$ & $10 \mathrm{D}$ & 11D & $12 \mathrm{E}$ & $13 E$ & $14 \mathrm{E}$ & $15 E$ & $16 \mathrm{E}$ \\
\hline \multirow{4}{*}{ 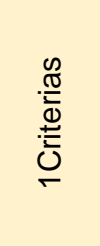 } & Fin & 0.28076 & 0.000 & 0.44444 & 0.07143 & 0.27347 & 0.000 & 0.000 & 0.000 & 0.000 & 0.000 & 0.000 & 0.000 & 0.000 & 0.000 & 0.000 & 0.000 & 0.000 & 0.000 & 0.000 & 0.000 & 0.000 \\
\hline & Man & 0.53042 & 0.16667 & 0.000 & 0.42857 & 0.05426 & 0.000 & 0.000 & 0.000 & 0.000 & 0.000 & 0.000 & 0.000 & 0.000 & 0.000 & 0.000 & 0.000 & 0.000 & 0.000 & 0.000 & 0.000 & 0.000 \\
\hline & Des & 0.13612 & 0.33333 & 0.05556 & 0.000 & 0.17227 & 0.000 & 0.000 & 0.000 & 0.000 & 0.000 & 0.000 & 0.000 & 0.000 & 0.000 & 0.000 & 0.000 & 0.000 & 0.000 & 0.000 & 0.000 & 0.000 \\
\hline & Exe & 0.05271 & 0.000 & 0.000 & 0.000 & 0.000 & 0.000 & 0.000 & 0.000 & 0.000 & 0.000 & 0.000 & 0.000 & 0.000 & 0.000 & 0.000 & 0.000 & 0.000 & 0.000 & 0.000 & 0.000 & 0.000 \\
\hline \multirow{16}{*}{ 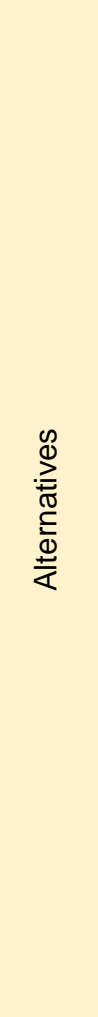 } & $1 F$ & 0.000 & 0.06250 & 0.000 & 0.000 & 0.000 & 0.000 & 0.53065 & 0.000 & 0.000 & 0.000 & 0.000 & 0.000 & 0.000 & 0.51121 & 0.000 & 0.56754 & 0.000 & 0.34652 & 0.000 & 0.000 & 0.000 \\
\hline & $2 F$ & 0.000 & 0.43750 & 0.000 & 0.000 & 0.000 & 1.00000 & 0.000 & 0.000 & 0.000 & 0.000 & 0.000 & 0.000 & 0.000 & 0.20571 & 0.000 & 0.000 & 0.000 & 0.22961 & 0.000 & 0.000 & 0.000 \\
\hline & $3 M$ & 0.000 & 0.000 & 0.08058 & 0.000 & 0.000 & 0.000 & 0.000 & 0.000 & 0.33436 & 0.70712 & 0.25266 & 0.000 & 0.000 & 0.000 & 0.000 & 0.000 & 0.000 & 0.000 & 0.000 & 0.000 & 0.000 \\
\hline & $4 M$ & 0.000 & 0.000 & 0.03377 & 0.000 & 0.000 & 0.000 & 0.000 & 0.71723 & 0.000 & 0.07015 & 0.05115 & 0.48000 & 0.000 & 0.000 & 0.000 & 0.000 & 0.000 & 0.04776 & 0.54848 & 0.000 & 0.000 \\
\hline & $5 \mathrm{M}$ & 0.000 & 0.000 & 0.28667 & 0.000 & 0.000 & 0.000 & 0.000 & 0.08808 & 0.24060 & 0.000 & 0.53488 & 0.000 & 0.000 & 0.000 & 0.000 & 0.000 & 0.000 & 0.09873 & 0.000 & 0.000 & 0.000 \\
\hline & $6 \mathrm{M}$ & 0.000 & 0.000 & 0.09898 & 0.000 & 0.000 & 0.000 & 0.000 & 0.19469 & 0.15656 & 0.22273 & 0.000 & 0.000 & 0.000 & 0.000 & 0.000 & 0.000 & 0.000 & 0.03851 & 0.000 & 0.000 & 0.000 \\
\hline & $7 D$ & 0.000 & 0.000 & 0.000 & 0.04194 & 0.000 & 0.000 & 0.22825 & 0.000 & 0.05123 & 0.000 & 0.000 & 0.000 & 0.74184 & 0.07206 & 0.000 & 0.12634 & 0.000 & 0.03966 & 0.23232 & 0.000 & 0.000 \\
\hline & $8 D$ & 0.000 & 0.000 & 0.000 & 0.01740 & 0.000 & 0.000 & 0.06796 & 0.000 & 0.18875 & 0.000 & 0.000 & 0.28995 & 0.000 & 0.14216 & 0.000 & 0.23557 & 0.000 & 0.02616 & 0.16333 & 0.000 & 0.000 \\
\hline & $9 D$ & 0.000 & 0.000 & 0.000 & 0.06313 & 0.000 & 0.000 & 0.04055 & 0.000 & 0.000 & 0.000 & 0.000 & 0.05536 & 0.07520 & 0.000 & 0.000 & 0.07055 & 0.000 & 0.04495 & 0.000 & 0.000 & 0.000 \\
\hline & $10 \mathrm{D}$ & 0.000 & 0.000 & 0.000 & 0.14433 & 0.000 & 0.000 & 0.000 & 0.000 & 0.000 & 0.000 & 0.000 & 0.000 & 0.000 & 0.000 & 0.75000 & 0.000 & 0.000 & 0.03538 & 0.000 & 0.000 & 0.000 \\
\hline & 11D & 0.000 & 0.000 & 0.000 & 0.23320 & 0.000 & 0.000 & 0.13259 & 0.000 & 0.000 & 0.000 & 0.000 & 0.000 & 0.000 & 0.02851 & 0.000 & 0.000 & 0.000 & 0.06310 & 0.000 & 0.000 & 0.000 \\
\hline & $12 \mathrm{E}$ & 0.000 & 0.000 & 0.000 & 0.000 & 0.03382 & 0.000 & 0.000 & 0.000 & 0.000 & 0.000 & 0.000 & 0.000 & 0.000 & 0.000 & 0.000 & 0.000 & 0.000 & 0.000 & 0.000 & 1.00000 & 0.000 \\
\hline & $13 \mathrm{E}$ & 0.000 & 0.000 & 0.000 & 0.000 & 0.26547 & 0.000 & 0.000 & 0.000 & 0.000 & 0.000 & 0.16132 & 0.07732 & 0.000 & 0.000 & 0.25000 & 0.000 & 0.000 & 0.000 & 0.05587 & 0.000 & 0.000 \\
\hline & $14 \mathrm{E}$ & 0.000 & 0.000 & 0.000 & 0.000 & 0.05795 & 0.000 & 0.000 & 0.000 & 0.02849 & 0.000 & 0.000 & 0.09737 & 0.18296 & 0.04035 & 0.000 & 0.000 & 0.000 & 0.02963 & 0.000 & 0.000 & 0.000 \\
\hline & $15 \mathrm{E}$ & 0.000 & 0.000 & 0.000 & 0.000 & 0.11394 & 0.000 & 0.000 & 0.000 & 0.000 & 0.000 & 0.000 & 0.000 & 0.000 & 0.000 & 0.000 & 0.000 & 1.00000 & 0.000 & 0.000 & 0.000 & 0.000 \\
\hline & $16 \mathrm{E}$ & 0.000 & 0.000 & 0.000 & 0.000 & 0.02881 & 0.000 & 0.000 & 0.000 & 0.000 & 0.000 & 0.000 & 0.000 & 0.000 & 0.000 & 0.000 & 0.000 & 0.000 & 0.000 & 0.000 & 0.000 & 0.000 \\
\hline
\end{tabular}


Appendix D: limited super matrix




Appendix E: Result of face and content validity

\begin{tabular}{|c|c|c|c|c|c|c|c|}
\hline \multirow{2}{*}{ No. } & \multirow{2}{*}{ Sub-Factors } & \multicolumn{5}{|c|}{ Result of Content Validity } & \multirow{2}{*}{$\begin{array}{l}\text { Result of } \\
\text { face } \\
\text { validity }\end{array}$} \\
\hline & & CVR & CVI-4 & CVI-3 & CVI-2 & CVI-1 & \\
\hline 1 & $\begin{array}{l}\text { Sudden rise in prices and lack of accurate } \\
\text { forecasting of inflation and adjustment in the } \\
\text { contract }\end{array}$ & $\sqrt{ }$ & $\sqrt{ }$ & $\sqrt{ }$ & $x$ & $\sqrt{ }$ & $\sqrt{ }$ \\
\hline 2 & $\begin{array}{l}\text { International sanctions and their impact on project } \\
\text { preparations }\end{array}$ & $\sqrt{ }$ & $\sqrt{ }$ & $\sqrt{ }$ & $x$ & $x$ & $\sqrt{ }$ \\
\hline 3 & $\begin{array}{l}\text { Delay in handling and payment of contractors' } \\
\text { statements }\end{array}$ & $\sqrt{ }$ & $\sqrt{ }$ & $\sqrt{ }$ & $\sqrt{ }$ & $\sqrt{ }$ & $x$ \\
\hline 4 & $\begin{array}{l}\text { Delay in determining the assignment of project } \\
\text { issues in different committees (commission of } \\
\text { transactions, contract affairs, management } \\
\text { control, planning and contractual support, etc.) }\end{array}$ & $\sqrt{ }$ & $x$ & $\sqrt{ }$ & $\sqrt{ }$ & $\sqrt{ }$ & $\sqrt{ }$ \\
\hline 5 & $\begin{array}{l}\text { Change in the representatives of the employer and } \\
\text { the supervision unit during the implementation } \\
\text { without coordination }\end{array}$ & $x$ & $\sqrt{ }$ & $\sqrt{ }$ & $\sqrt{ }$ & $x$ & $x$ \\
\hline 6 & $\begin{array}{l}\text { Incompatibility of the expertise of the project } \\
\text { manager with the nature of the project }\end{array}$ & $x$ & $\sqrt{ }$ & $\sqrt{ }$ & $\sqrt{ }$ & $\sqrt{ }$ & $x$ \\
\hline 7 & $\begin{array}{l}\text { Eliminate open contracts to complete unforeseen } \\
\text { cases in the plan }\end{array}$ & $x$ & $x$ & $\sqrt{ }$ & $x$ & $x$ & $x$ \\
\hline 8 & $\begin{array}{l}\text { Selection of weak contractors to implement } \\
\text { projects }\end{array}$ & $\sqrt{ }$ & $\sqrt{ }$ & $\sqrt{ }$ & $\sqrt{ }$ & $x$ & $\sqrt{ }$ \\
\hline 9 & $\begin{array}{l}\text { Lack of sufficient authority for project lead in } \\
\text { implementation unit }\end{array}$ & $\sqrt{ }$ & $\sqrt{ }$ & $\sqrt{ }$ & $\sqrt{ }$ & $\sqrt{ }$ & $\sqrt{ }$ \\
\hline 10 & $\begin{array}{l}\text { Complex regulation bureaucracy (supply of } \\
\text { mechanism, entry and exit of materials, supply of } \\
\text { manpower) }\end{array}$ & $x$ & $\sqrt{ }$ & $\sqrt{ }$ & $\sqrt{ }$ & $\sqrt{ }$ & $\sqrt{ }$ \\
\hline 11 & $\begin{array}{l}\text { Failure to notify the contract at the appropriate } \\
\text { time of work }\end{array}$ & $x$ & $\sqrt{ }$ & $\sqrt{ }$ & $\sqrt{ }$ & $\sqrt{ }$ & $\times$ \\
\hline 12 & $\begin{array}{l}\text { Lack of completion and timely notification of } \\
\text { project documentation by the supervisory unit }\end{array}$ & $\sqrt{ }$ & $\sqrt{ }$ & $\sqrt{ }$ & $\sqrt{ }$ & $\sqrt{ }$ & $x$ \\
\hline 13 & $\begin{array}{l}\text { Lack of timely issuance of work permit (inside } \\
\text { workshop) by operators }\end{array}$ & $\sqrt{ }$ & $\sqrt{ }$ & $\sqrt{ }$ & $\sqrt{ }$ & $\sqrt{ }$ & $\sqrt{ }$ \\
\hline 14 & $\begin{array}{l}\text { Lack of central role for project lead in execution } \\
\text { stages (scattering of decision-makers in projects) }\end{array}$ & $\sqrt{ }$ & $\sqrt{ }$ & $\sqrt{ }$ & $\sqrt{ }$ & $\sqrt{ }$ & $\sqrt{ }$ \\
\hline 15 & $\begin{array}{l}\text { Lack of executive project team with different } \\
\text { specialties and suitable for the project }\end{array}$ & $\sqrt{ }$ & $\sqrt{ }$ & $\sqrt{ }$ & $\sqrt{ }$ & $\sqrt{ }$ & $x$ \\
\hline 16 & $\begin{array}{l}\text { Lack of specialized organizational structure } \\
\text { specially in contractors and supervisors }\end{array}$ & $\sqrt{ }$ & $\sqrt{ }$ & $\sqrt{ }$ & $\sqrt{ }$ & $\sqrt{ }$ & $\sqrt{ }$ \\
\hline 17 & $\begin{array}{l}\text { Lack of sufficient workflow to implement } \\
\text { processes in the implementation deputy }\end{array}$ & $x$ & $\sqrt{ }$ & $\sqrt{ }$ & $\sqrt{ }$ & $\sqrt{ }$ & $x$ \\
\hline 18 & $\begin{array}{l}\text { Lack of engineering coordination between } \\
\text { factory, operators, and executors of the initial } \\
\text { plans (especially in EPC projects) }\end{array}$ & $\sqrt{ }$ & $\sqrt{ }$ & $\sqrt{ }$ & $\sqrt{ }$ & $\sqrt{ }$ & $\sqrt{ }$ \\
\hline 19 & $\begin{array}{l}\text { Lack of integration in the views of project } \\
\text { stakeholders }\end{array}$ & $\sqrt{ }$ & $\sqrt{ }$ & $\sqrt{ }$ & $\sqrt{ }$ & $\sqrt{ }$ & $x$ \\
\hline 20 & $\begin{array}{l}\text { Lack of human resources in the implementation } \\
\text { unit }\end{array}$ & $x$ & $\sqrt{ }$ & $\sqrt{ }$ & $\sqrt{ }$ & $\sqrt{ }$ & $x$ \\
\hline 21 & $\begin{array}{l}\text { Failure to delegate sufficient authority to the } \\
\text { operating representative }\end{array}$ & $x$ & $x$ & $x$ & $\sqrt{ }$ & $x$ & $\sqrt{ }$ \\
\hline 22 & $\begin{array}{l}\text { Insufficient specialized training in the field of } \\
\text { workflow and project management }\end{array}$ & $x$ & $\sqrt{ }$ & $\sqrt{ }$ & $\sqrt{ }$ & $\sqrt{ }$ & $\sqrt{ }$ \\
\hline 23 & $\begin{array}{l}\text { Numerous decision-making points in the project } \\
\text { (outside of implementation deputy) }\end{array}$ & $\sqrt{ }$ & $\sqrt{ }$ & $\sqrt{ }$ & $\sqrt{ }$ & $\sqrt{ }$ & $\sqrt{ }$ \\
\hline 24 & $\begin{array}{l}\text { Lack of necessary permits from units involved in } \\
\text { the project for land preparation, conflict } \\
\text { resolution, workshop outfitting, etc. }\end{array}$ & $\sqrt{ }$ & $\sqrt{ }$ & $\sqrt{ }$ & $\sqrt{ }$ & $\sqrt{ }$ & $\sqrt{ }$ \\
\hline 25 & $\begin{array}{l}\text { Prolonged process change plan during the } \\
\text { implementation phase }\end{array}$ & $\sqrt{ }$ & $\sqrt{ }$ & $\sqrt{ }$ & $\sqrt{ }$ & $\sqrt{ }$ & $x$ \\
\hline 26 & $\begin{array}{l}\text { Lack of necessary coordination for the product of } \\
\text { the project in the plans }\end{array}$ & $\sqrt{ }$ & $\sqrt{ }$ & $\sqrt{ }$ & $x$ & $\sqrt{ }$ & $\sqrt{ }$ \\
\hline 27 & Lack of correct prediction of contract schedule & $\sqrt{ }$ & $\sqrt{ }$ & $\sqrt{ }$ & $\sqrt{ }$ & $\sqrt{ }$ & $\sqrt{ }$ \\
\hline 28 & $\begin{array}{l}\text { Lack of correct prediction of require time for land } \\
\text { and workshop equipment preparation }\end{array}$ & $\sqrt{ }$ & $\sqrt{ }$ & $\sqrt{ }$ & $\sqrt{ }$ & $\sqrt{ }$ & $\sqrt{ }$ \\
\hline 29 & $\begin{array}{l}\text { Lack of budget predictions for new activities in } \\
\text { contracts }\end{array}$ & $\sqrt{ }$ & $\sqrt{ }$ & $\sqrt{ }$ & $\sqrt{ }$ & $\sqrt{ }$ & $\sqrt{ }$ \\
\hline
\end{tabular}




\begin{tabular}{|c|c|c|c|c|c|c|c|}
\hline \multirow{2}{*}{ No. } & \multirow{2}{*}{ Sub-Factors } & \multicolumn{5}{|c|}{ Result of Content Validity } & \multirow{2}{*}{$\begin{array}{l}\text { Result of } \\
\text { face } \\
\text { validity }\end{array}$} \\
\hline & & CVR & CVI-4 & CVI-3 & CVI-2 & CVI-1 & \\
\hline 30 & $\begin{array}{l}\text { Failure to anticipate the requirements of the } \\
\text { requirements (electricity, water, etc.) to equip the } \\
\text { site at the time of design and obtain approval of } \\
\text { operators }\end{array}$ & $\sqrt{ }$ & $x$ & $\sqrt{ }$ & $\sqrt{ }$ & $x$ & $\sqrt{ }$ \\
\hline 31 & $\begin{array}{l}\text { Absence of an executive representative in the } \\
\text { bidding process and review of documents }\end{array}$ & $x$ & $\sqrt{ }$ & $\sqrt{ }$ & $\sqrt{ }$ & $\sqrt{ }$ & $\sqrt{ }$ \\
\hline 32 & $\begin{array}{l}\text { Lack of transparency in general and specific } \\
\text { contract conditions of MSC }\end{array}$ & $\sqrt{ }$ & $\sqrt{ }$ & $\sqrt{ }$ & $\sqrt{ }$ & $\sqrt{ }$ & $\sqrt{ }$ \\
\hline 33 & $\begin{array}{l}\text { Not filling project documents before tender } \\
\text { (including maps, operator confirmations, } \\
\text { providers' list, etc.) }\end{array}$ & $\sqrt{ }$ & $\sqrt{ }$ & $\sqrt{ }$ & $\sqrt{ }$ & $\sqrt{ }$ & $\sqrt{ }$ \\
\hline 34 & $\begin{array}{l}\text { Incompatibility between project implementation } \\
\text { method and contract type (BOT, PC, EPC, etc.) }\end{array}$ & $\sqrt{ }$ & $\sqrt{ }$ & $\sqrt{ }$ & $\sqrt{ }$ & $\sqrt{ }$ & $\sqrt{ }$ \\
\hline 35 & $\begin{array}{l}\text { Inconsistency of technical specifications of } \\
\text { contract with steel industry requirements and } \\
\text { standards }\end{array}$ & $\sqrt{ }$ & $\sqrt{ }$ & $\sqrt{ }$ & $\sqrt{ }$ & $\sqrt{ }$ & $x$ \\
\hline 36 & $\begin{array}{l}\text { Inconsistence of plans with estimates attached to } \\
\text { the contract }\end{array}$ & $\sqrt{ }$ & $\sqrt{ }$ & $\sqrt{ }$ & $\sqrt{ }$ & $\sqrt{ }$ & $\sqrt{ }$ \\
\hline 37 & $\begin{array}{l}\text { The complexity of the administrative cycle in } \\
\text { sending correspondence between real } \\
\text { stakeholders }\end{array}$ & $x$ & $\sqrt{ }$ & $\sqrt{ }$ & $\sqrt{ }$ & $x$ & $\sqrt{ }$ \\
\hline 38 & $\begin{array}{l}\text { Weaknesses in executive management of the } \\
\text { contractors }\end{array}$ & $\sqrt{ }$ & $\sqrt{ }$ & $\sqrt{ }$ & $\sqrt{ }$ & $\sqrt{ }$ & $\sqrt{ }$ \\
\hline 39 & $\begin{array}{l}\text { Inaccurate implementation of project quality } \\
\text { control workflow }\end{array}$ & $x$ & $\sqrt{ }$ & $\sqrt{ }$ & $\sqrt{ }$ & $\sqrt{ }$ & $x$ \\
\hline 40 & $\begin{array}{l}\text { Failure to hold weekly workshop meetings to } \\
\text { control project progress }\end{array}$ & $\sqrt{ }$ & $\sqrt{ }$ & $\sqrt{ }$ & $\sqrt{ }$ & $\sqrt{ }$ & $x$ \\
\hline 41 & Lack of timely approval of initial schedule & $\sqrt{ }$ & $\sqrt{ }$ & $\sqrt{ }$ & $x$ & $\sqrt{ }$ & $\sqrt{ }$ \\
\hline 42 & $\begin{array}{l}\text { Failure to appoint members of the delivery team } \\
\text { at the beginning of the project }\end{array}$ & $\sqrt{ }$ & $\sqrt{ }$ & $\sqrt{ }$ & $\sqrt{ }$ & $\sqrt{ }$ & $x$ \\
\hline 43 & $\begin{array}{l}\text { Failure to complete and notify project documents } \\
\text { in a timely manner, including the minutes of } \\
\text { approval operations and etc. }\end{array}$ & $\sqrt{ }$ & $\sqrt{ }$ & $\sqrt{ }$ & $\sqrt{ }$ & $\times$ & $x$ \\
\hline 44 & $\begin{array}{l}\text { Failure to provide accurate weekly reports by the } \\
\text { project manager }\end{array}$ & $x$ & $\sqrt{ }$ & $\sqrt{ }$ & $\sqrt{ }$ & $\times$ & $\times$ \\
\hline 45 & $\begin{array}{l}\text { Lack of sufficient insistence of supervising units } \\
\text { for timely delivery of the project }\end{array}$ & $\sqrt{ }$ & $\sqrt{ }$ & $\sqrt{ }$ & $\sqrt{ }$ & $\sqrt{ }$ & $\sqrt{ }$ \\
\hline 46 & $\begin{array}{l}\text { Non-compliance of organizational hierarchy in } \\
\text { communication with the employer by the } \\
\text { contractor }\end{array}$ & $x$ & $\sqrt{ }$ & $\sqrt{ }$ & $\sqrt{ }$ & $\sqrt{ }$ & $\sqrt{ }$ \\
\hline 47 & $\begin{array}{l}\text { Insufficient study and review of the contract } \\
\text { notified before the start of the implementation due } \\
\text { to project risks }\end{array}$ & $\sqrt{ }$ & $\sqrt{ }$ & $\sqrt{ }$ & $\sqrt{ }$ & $x$ & $\sqrt{ }$ \\
\hline 48 & $\begin{array}{l}\text { The incompatibility of individuals in the } \\
\text { supervisory unit chart with the actual amount } \\
\text { required }\end{array}$ & $x$ & $\sqrt{ }$ & $\sqrt{ }$ & $\sqrt{ }$ & $\sqrt{ }$ & $\sqrt{ }$ \\
\hline
\end{tabular}

